\title{
A geological collection and methodology for tracing the provenance of Palaeolithic colouring materials
}

\author{
Hélène Salomon ${ }^{1}$, Claire Chanteraud ${ }^{1}$, Aurélie Chassin de Kergommeaux ${ }^{1}$, \\ Julien Monney ${ }^{1}$, Jean-Victor Pradeau ${ }^{2}$, Eric Goemaere ${ }^{3}$, Yvan Coquinot ${ }^{4}$, \\ Émilie Chalmin ${ }^{1}$
}

1. Université Savoie Mont-Blanc, CNRS, EDYTEM. 5 bd de la Mer Caspienne, F-73376 Le Bourget du Lac cedex, France. Email: Salomon: helene.salomon@univ-smb.fr; Chanteraud: claire.chanteraud@hotmail.fr; Chassin de Kergommeaux: aurelie.chassin-de-kergommeaux@univ-smb.fr; Monney: julien@monocycle.ch; Chalmin: emilie.chalmin-aljanabi@univ-smb.fr

2. Independent researcher. Rue Jean-Louis de Bons 9, CH-1006 Lausanne, Switzerland.

Email: jvpradeau@gmail.com

3. Geological Survey of Belgium, Royal Belgian Institute of Natural Sciences. Rue Vautier, 29, B-1000, Bruxelles, Belgium. Email: eric.goemaere@naturalsciences.be

4. Centre de Recherche et de Restauration des Musées de France (C2RMF). Ministère de la Culture, 14 quai

François Mitterrand F-75001 Paris, France. Email: yvan.coquinot@culture.gouv.fr

\begin{abstract}
:
Although prehistoric sites frequently contain numerous fragments and traces of many different kinds of colouring matter, intensive study of this type of archaeological remains began only recently. Such studies, aimed at determining how raw materials formed and changed over time, and how they were transported by the groups of humans who used them, are extremely valuable as they reveal shared strategies, that is, cultural traditions and the spaces in which they developed. The scope of this paper focusses on the description of the main geological contexts in which ferruginous colouring materials form and are found. In the framework of a collective research program called Pigmentothèque (iron- and manganese-rich rocks and minerals library), geological surveys are conducted taking into consideration the geological settings in which colouring materials are present and using a common record and sampling methodology which is followed by petrophysical, mineralogical and chemical analyses based on a shared procedure and vocabulary. In order to go beyond descriptions based solely on colour and chemical composition, we describe the great variety of iron-rich materials that can be used to obtain colouring matter. This diversity in the formation and evolution of iron-rich materials must be taken into account when trying to understand past humans' choices of raw materials, their provenance and the anthropogenic and natural modifications they have undergone. We also describe criteria for recognising cohesive remains of colouring matter during archaeological excavations, so these artefacts can take their place alongside other mineral resources in helping improve our understanding of past societies.
\end{abstract}

Keywords: iron-rich materials; provenance; sourcing; ochre; pigment; Palaeolithic; reference samples; petroarchaeology

Published by the School of History, Classics and Archaeology, University of Edinburgh ISSN: 2055-0472. URL: http://journals.ed.ac.uk/lithicstudies/

Except where otherwise noted, this work is licensed under a CC BY 4.0 licence. 


\section{Introduction}

Scholars have been interested in the utilisation of colouring matter since the earliest days of research into prehistoric cultures (e.g., Lartet \& Christy 1875: 60-61, 94, 109, 297; Moissan 1902; 1903; de Mortillet \& de Mortillet 1900: 555; Rivière 1887: 196), but studies of this category of archaeological remains from the perspective of chaînes opératoires began only about a decade ago. Colouring matter is often referred to as "ochre", a term with a multitude of sometimes contrasting meanings that has been applied to everything from black pigments derived from manganese-rich materials to the reds, oranges and yellows obtained from iron-rich substances. This lack of precision can be attributed partly to the word's roots in the Greek ókhra, from ōkhrós, which simply means pale, haggard or wan. Another, perhaps more important, explanation for ochre's widely divergent, almost antithetical meanings, is the fact that it has long been used interchangeably to refer to colour, colouring matter and raw material (Salomon 2009: 46, 51-52; Triat 2010: 16-17; Tromeur 1998: 5-9). This lexical vacillation is omnipresent, but it means the term ochre (ocher in US English) provides little information about either the colour or hue (yellow, orange, red, brown, light, dark, etc.) or the material (in its natural state or transformed by humans, pigmentaceous minerals, rocks rich in pigmentaceous minerals).

In addition, colouring matter occurs in numerous forms, ranging from blocks and fragments, either in their natural state or modified by human actions, to its most common form: small flakes or powders, in varying states of preservation. Powders are found mixed into sediment, daubed on rock walls and applied to the surfaces of all types of artefacts, including knapped and unknapped stone tools, tools made from hard animal tissue, body ornaments, portable art pieces, and, in some funerary contexts, on skeletons. Nevertheless, despite the wide occurrence of colouring matter, scholars have only recently begun investigating its provenance and production. As for siliceous matter and shells, studies of archaeological colouring matter can provide insights into the journeys undertaken by past humans and thereby throw light onto patterns of movement of human groups within a geographical area, and even patterns of land use.

The first step in understanding Palaeolithic supply strategies, the exploitation of colouring matter, where it was used, and the individual and collaborative effort invested in the technological and value systems involved is to identify the different raw materials available in the environment and the characteristics they acquired as they evolved. By analysing raw material exploitation methods, technological possibilities and constraints, and individual and collective skills, it is possible to determine shared strategies and knowledge, and technical practices and cultural values. Identifying the sources and characteristics of the resources used is fundamental to understanding chaînes opératoires. It also provides insights into the choices the resources' users made and the links between sequences (procurement, technical transformation, utilisation).

A Collaborative Research Project (PCR) called Pigmentothèque (a colouring matter library), led by Emilie Chalmin and Hélène Salomon (financed by the Auvergne-Rhône-Alpes Regional Council Department of Cultural Affairs), was set up to address these issues. This paper presents an overview of the wide diversity of the geological contexts in which ironcontaining materials may be found. It describes the methodological framework drawn up for the Pigmentothèque's research and presents the project's collection of iron-rich rocks in order to show how this approach can be used to investigate ferruginous-matter procurement strategies (Chassin de Kergommeaux et al. 2021). Although the examples presented in the following are mainly French, they can be applied to a wider geographical and geological area (for instance, Dayet et al. 2017; MacDonald et al. 2018; Mauran et al. 2021; Velliky et al. 2019). 


\section{The issue of provenance: of territories and materials}

\subsection{Colouring raw materials, circulation networks and territory}

Prehistoric territories are defined by identifying cultural groups with codes and norms founded on shared knowledge (Aubry 2005; Bon 2009: 250). Although the notion of territory differs from one discipline to another, prehistoric archaeologists consider a territory to be a culturally occupied space (recognized by groups that live within the space) that is exploited economically and where culture, rituals and socially-constructed and material resources are handed down from generation to generation (Binford 1979: 259; Godelier 1984: 101-115; 1986: 90-102; 2009: 97). By ensuring access to mineral and living resources, groups of humans staked out territories that were constructed and deconstructed over time and which can be seen as networks of places made of relationships between materials, humans, settlements and movements (Binford 1980; Bon 2009: 254; Delvigne et al. in press; Gould \& Saggers 1985). Although this is a major issue in prehistoric archaeology, identifying the area of prehistoric territories on the basis of linear links between supply location and settlements where materials were left comes up against major pitfalls. Indeed, the transport of resources between one point and another can be handled by: (i) several different groups not recognising a common identity, but exchanging raw materials from one group to another, or (ii) one group crossing the territories of other groups in order to obtain resources. Therefore, the movement of raw materials cannot be seen as a direct reflection of the territorial hold of a given group. For these reasons, we are not able to distinguish direct acquisitions and exchange, and thus to establish the limits of territories through the acquisition of raw materials. On the other hand, the approach allows us to reconstruct networks of resources' circulation and, by extension, networks of human circulation at a given period. Hence, studies of prehistoric societies are based on recognising systems for exploiting resources within networks of places e.g., between several human settlements, mineral deposits, rock art sites (Bourdier 2013; Monney 2012).

The few ethno-historical and ethnographic documents that mention the procurement of colouring materials (mostly red) tell of how costly such expeditions were for human groups, whether because of the difficulty of the journeys (long, dangerous), the exchanges of goods that took place during them, or the sometimes violent contacts with other groups that held sovereignty over the resources being sought. Jones (1984) recounts the quest of "ochre seekers" in Australia, small groups separated from their tribe that travelled up to $1,000 \mathrm{~km}$ across adversaries' territories, paying rights of way and obeying the access rules and codes needed to obtain a red material (called "ochre") that was considered sacred and known for its quality. Other scholars have described similar expeditions by the OvaHimba in Namibia (Rifkin 2012a) and by various hunter-gatherers in North America (Kenyon 1980: 151). But these epic journeys are unlikely to be the rule. Because the subject of how nomads obtained the colouring raw materials they needed has rarely been addressed, it is the most surprising practices that have grabbed the attention of observers, who have described these practices without specifically considering the material being sought. Thus, cases of collecting materials close to dwellings may not have been described. Moreover, it is control over socially constructed and material resources, not the distances travelled, that define living spaces and frequented places (Godelier 1984: 105-106; 1986: 93-94).

\subsection{History of research on the provenance of colouring matter used during the Palaeolithic}

Unlike the provenance of the siliceous raw materials used to make tools, which has been studied since the earliest days of prehistoric research (Damour 1865), the geological and 
geographical origins of the raw colouring matter found in prehistoric settlements and rock art sites has only recently attracted the interest of researchers. Because prehistorians' interest in colouring matter initially focused on authenticating, conserving and producing replicas of decorated caves (Moissan (1902; 1903); Courty (1902); then Couraud \& Laming-Emperaire (1979) at Lascaux; Cabrera-Garrido (1978) at Altamira), it was not until the 1980s and 1990s that scholars began paying attention to colouring matter and coloured materials in contexts without proven rock art (Lower and Middle Palaeolithic, settlements; see Audouin \& Plisson 1982; Beyries \& Inizan 1982; Beyries \& Walter 1996; Couraud 1983, 1991; Demars 1992; Onoratini 1985; San Juan 1990). The scientific value of these remains has now been generally accepted, following a multitude of studies aimed at analysing and characterising the vast corpus of cohesive colouring matter that has retained its petrographic structure, whether it is raw or mechanically processed, rather than colouring matter applied to tools, portable art objects or rock walls (Beck et al. 2012; Billard et al. 2016: 17-20, 221-226; Dayet 2012; Pradeau 2015; Pradeau et al. 2014; Regert 1995; Salomon 2003; 2004; 2009). To date, these studies have tended to adopt a site-centred approach, focusing on an area around a specific archaeological site. Pradeau's (2015): 166-170 systematic study of certain types of ferruginous rocks is a notable exception to this rule.

In addition, most studies have focused on chemical and mineralogical analyses of colouring materials, especially elemental analyses (see Salomon et al. 2016, for a summary), and neglected the rocks' petrographic characteristics. However, elemental analyses alone rarely provide sufficient information to confidently attribute an archaeological object to a geological formation or a source (Beck et al. 2012; Dayet et al. 2015; Eiselt et al. 2011; Goemaere et al. 2016b; 2016c; MacDonald et al. 2018; Pradeau 2015: 248-254; Pradeau et al. 2016; Salomon et al. 2014; 2016). Hence, geochemical and mineralogical analyses must be combined with petrographic analyses, which can throw light onto how materials have evolved, both chemically and physically, between their formation and their discovery at an archaeological site. Comprehending the multiplicity of these rocks and minerals, taking into account both the great diversity of modes by which they formed and evolved and the variability that occurs within deposits, is a prerequisite for determining the source of a sample of colouring matter. The present paper helps meet this need by providing brief descriptions of the materials used as colouring matter and the main settings in which they formed.

\section{Rocks and minerals used as colouring matter during the Palaeolithic}

Materials used as colouring matter contain a mineral pigment that, when reduced to a powder, can give its colour to other materials, either by masking the initial colour or by blending with the substrate (Pradeau 2015: 35-36). The colouring materials used during the Palaeolithic were derived from a wide variety of rocks (Onoratini 1985), most of which were composed of or coloured by iron ox(hydrox)ides (reds, yellows, browns, oranges, purples, blacks) or manganese ox(hydrox)ides (browns and blacks). Such rocks form in many different settings. Hematite $\left(\alpha-\mathrm{Fe}_{2} \mathrm{O}_{3}\right.$, red to violet) often occurs in association with goethite $(\alpha-$ $\mathrm{FeO}(\mathrm{OH})$, yellow to brown) and with mixtures of other iron ox(hydrox)ides showing greateror-lesser degrees of hydration and crystallisation (formerly called limonite) (Cornell \& Schwertmann 2003: 9-19). Manganese oxides and hydroxides (blacks), either pure or containing barium and other cations, are components of many minerals (Chalmin 2003: 4176).

Although Palaeolithic humans used only a small number of colours, they occur in a wide range of shades due to differences in the crystallinity, granulometry and relative proportions of each mineral, mixing with different mineral phases within a rock, and the rock's porosity (Cornell \& Schwertmann 2003: 409-468; Routhier 1963: 700-788; Salomon et al. 2019; Triat 
2010: 19-29). As mentioned earlier, ochre is often used to designate all colouring materials that are rich in iron (or manganese) ox(hydrox)ides (or kaolin in some cases), whatever their colour (Brooks et al. 2018; David et al. 2019; Mackay \& Welz 2008; Rifkin 2012b: 149; Watts 2002; Wreschner 1980). Nonetheless, other authors describe these materials more precisely as natural mixes of clay minerals and iron ox(hydrox)ides, possibly containing quartz (Bar-Yosef-Mayer et al. 2009; Cavallo et al. 2017; Cuenca-Solana et al. 2016; Dayet et al. 2017; Eisel et al. 2011; d'Errico et al. 2010; 2012; Glavenchuk 2012; Henshilwood et al. 2009; 2011; Hodgskiss \& Wadley 2017; Hovers et al. 2003; Iriarte et al. 2009; MacDonald et al. 2018; Popelka-Filcoff \& Charrison 2012; Rifkin 2012a; Rosso et al. 2014; Sajó et al. 2015; Velliky et al. 2018; Wadley 2013; Zipkin et al. 2017). However, the settings in which pigmentaceous materials formed, whether sedimentary (marine, continental, regolithic) or associated with magmatic, metamorphic or hydrothermal activity, vary greatly and thereby produce different mineral suites (Blot 2002; 2004; Denayer 2016; Jébrak \& Marcoux 2008: 42-45; Rossi \& Gasquet 2014). This is why the term ochre is no more suitable as a general term for all iron-rich pigmentaceous materials than as a description of their colour. Hence, ochre should not be used in place of more precise terms, especially because the great genetic and evolutionary variety of pigmentaceous materials makes them excellent geomarkers (Blot 2004; Dayet et al. 2017; Denayer 2016; Goemaere et al. 2016a; Jébrak \& Marcoux 2008: 42; Pradeau et al. 2016; Rossi \& Gasquet 2014; Thiry et al. 2006), as this paper aims to show in the case of ferruginous materials.

Iron-rich formations can be classified into three main types according to the source of the iron and the segregation mechanisms to which it has been subjected. In most of these formation types, bacteria may have contributed to (or even are responsible of) the concentration or oxidation of iron (Audra et al. 2011; Cavallo et al. 2018; Dubinina et al. 2012; Lenehan et al. 2017; Levett et al. 2020; MacDonald et al. 2019; Mamet \& Boulvain 1990; Mamet \& Préat 2003; Préat et al. 1999; 2000).

\subsection{Type I: Sedimentary iron formations}

Type I: Sedimentary iron formations (Figure 1: 1) contain iron that was deposited at the same time as the sediment or that was mobilised during diagenesis (Denayer 2016; Jébrak \& Marcoux 2008: 344-352; Rossi \& Gasquet 2014).

Banded-iron formations (BIFs) are Precambrian rocks formed by the chemical precipitation of iron and silica. They consist of alternating layers of iron oxides (hematite or magnetite, often black or silver) and red cherts, sometimes interbedded with calcareous shales (Figure 2: a-b), although they may also contain iron carbonates (siderite), silicates (greenalite or minnesotaite) or sulphides (pyrite). BIFs are the source of most of the world's commercially exploited iron ore, with particularly large deposits in Australia, Canada and Africa (Cornell \& Schwertmann 2003: 409 \& 416; Jébrak \& Marcoux 2008: 346; Robb 2005: 302-309). 
Geological diversity

of iron-rich formations

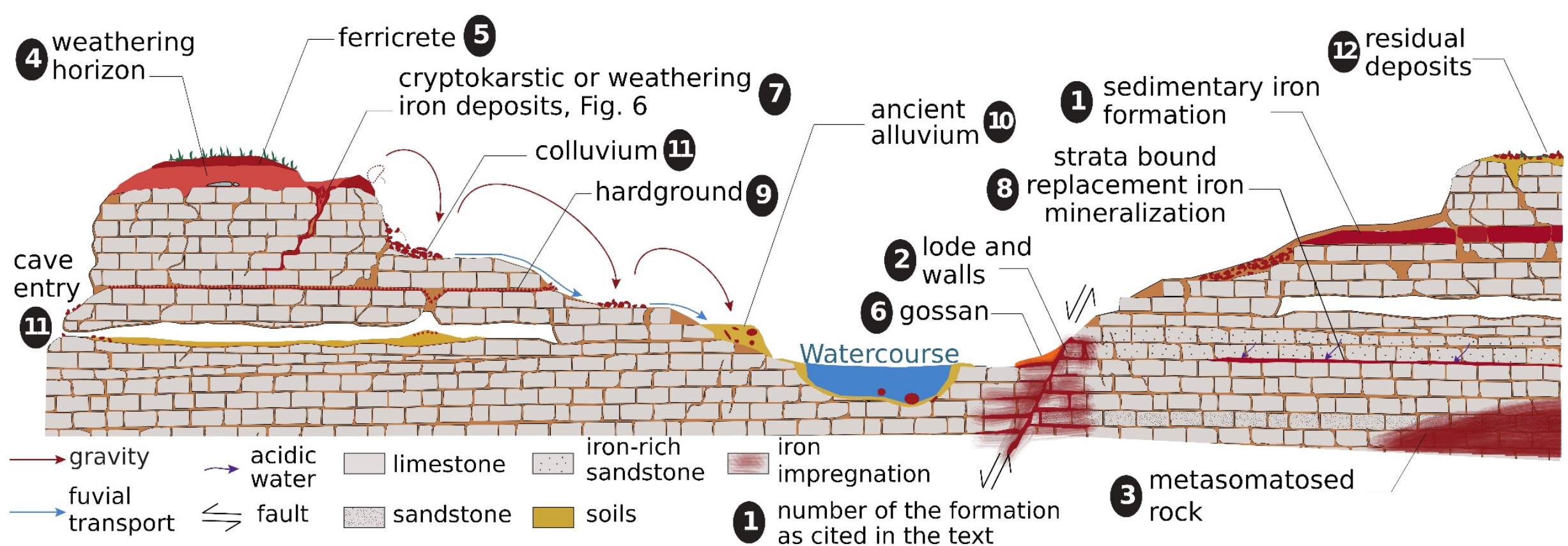

Figure 1. Diversity of iron formations and evolution of deposits. Without attempting to be comprehensive, this diagram shows the main types of formation and most important weathering situations, in order to illustrate the idea of an evolutionary chain (Fernandes \& Raynal 2006). Diagram: C. Chanteraud and A. Chassin de Kergommeaux, modified after Chanteraud (2020: 46). 

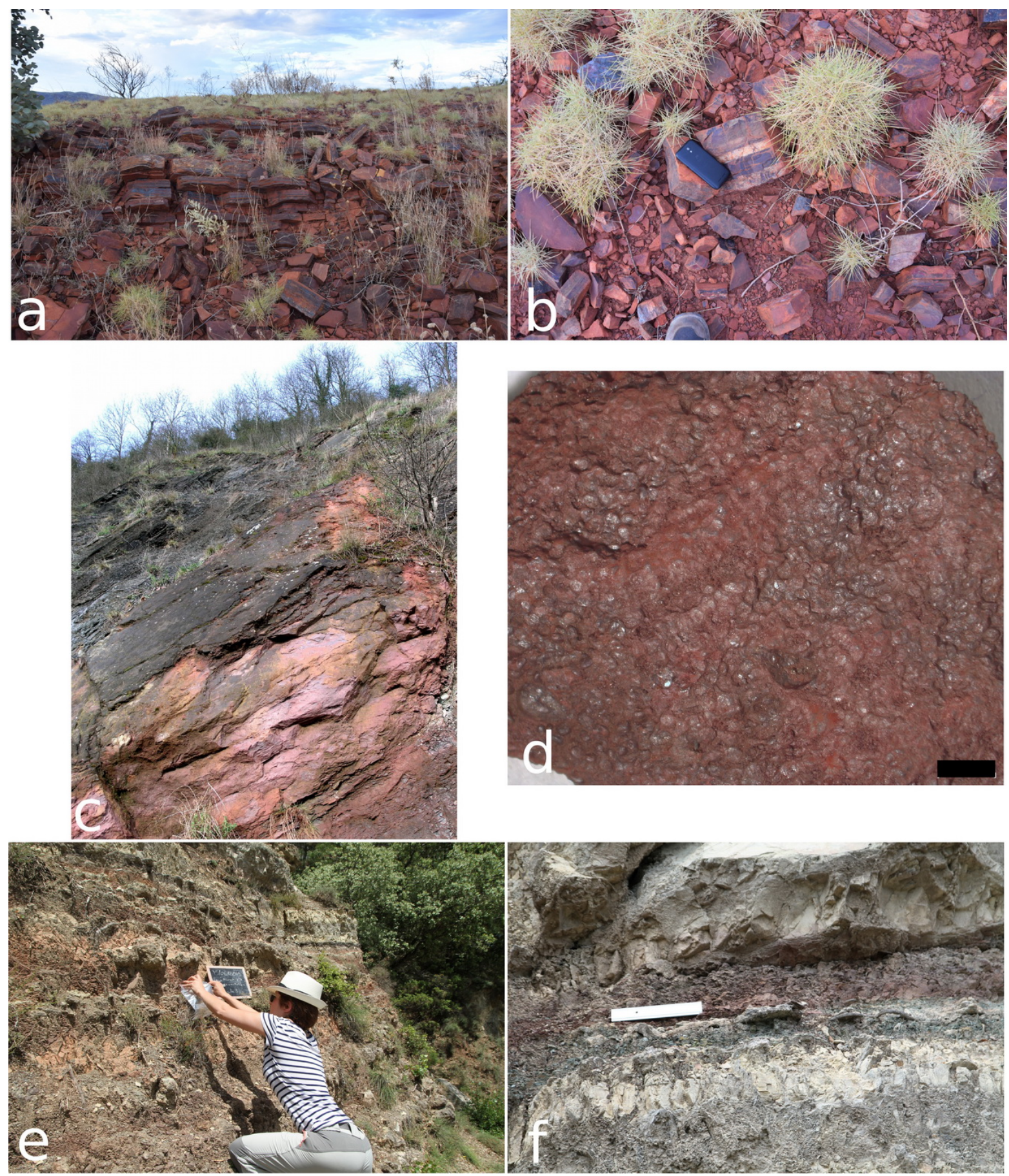

Figure 2. a-b) Banded Iron Formation, Rio Tinto's Marandoo mine, Western Australia, c-d) Oolitic ironstone (Clinton type) interbedded between Frasnian and Lower Famennian shales, Huy, Wallonia, Belgium, c) about 6 m high, d) scale bar; 2 mm e-f) Lias ferruginous marl interbedded with limestone, Molière, Gard, France, scale bar: 20 cm. Photos: a \& b: A. Chassin de Kergommeaux, c: E. Goemaere, d to f: H. Salomon.

Oolitic ironstones (Figure 2: c-d) are sedimentary rocks containing iron derived from continental weathering. Most oolitic ironstones formed during the Phanerozoic. They frequently occur as red-to-brown, oolite-rich lenticular bodies interbedded with calcareous, clayey or sandy rocks that were deposited in shallow marine environments or, very rarely, lakes (Cornell \& Schwertmann 2003: 416-420; Denayer 2016; Dreesen et al. 2016; Robb 2005: 300-301). Oolitic ironstones are composed of iron-rich ooids, which are small (less than $2 \mathrm{~mm}$ in diameter), concentrically layered spheroidal grains that form around a nucleus, 
which may be a mineral grain, bioclast or lithoclast. The layers or the nuclei (or both) are made of iron ox(hydrox)ide (goethite, hematite), iron carbonate (siderite), iron silicate (berthierine) or iron chlorite (chamosite). Oolitic ironstones are divided into two types - called Clinton and Minette - on the basis of their composition and how they formed (Dreesen et al. 2016; Evans 1993: 257). For example, in Europe, Clinton-type oolitic ironstones formed during the Ordovician, e.g., in Normandy, France, (Dreesen et al. 2016; Goemaere et al. 2016a), during the Devonian, e.g., in southern Belgium and in the Eifel Mountains of Germany (Dreesen et al. 2016; Denayer 2016; Goemaere et al. 2016a) (Figure 2: c-d), during the Hettangian, e.g., in the Ardèche, France (Cayeux 1909: 720-726, 767-786), and during the Toarcian, e.g., in the Aveyron and Deux-Sèvres, France; deposits include ferruginous oolites with ferruginised ammonites, often called Ammonitico Rosso (Galbrun et al. 1994). Minettetype deposits formed during the Upper Bajocian, e.g., in Normandy (Pavia et al. 2015) and during the Aalenian and Bajocian, e.g., in Lorraine, France, and in Luxembourg (Dreesen et al. 2016; Waterlot et al. 1973: 186).

Ferruginous marls, mudstones, siltstones and sandstones (Figure: 2 e-f) are red or yellow, continental or marine sedimentary formations, most of which formed during the Upper Palaeozoic, Lower Mesozoic or Upper Cenozoic. These formations stand out clearly in the landscape. The iron, which may be of detrital or diagenetic origin, permeates the sediment and cements the grains. Diagenetic, authigenic and automorphic iron ox(hydrox)ides form by the oxidation of pre-existing minerals such as glauconite, magnetite, biotite and ferromagnesian minerals, or by the pseudomorphosis of goethite, biotite or pyrite (Cornell \& Schwertmann 2003: 413-416; Vinchon 1984: 268-274).

Iron ox(hydrox)ide-rich matter also forms in other, more localised, mostly continental sedimentary formations. Bog iron stones (Denayer et al. 2011; Thelemann et al. 2017) are recent or sub-recent deposits that form in northern-hemisphere lakes and marshes when oxidation-reduction reactions result in iron precipitating out of iron-rich waters (Stanton 1972: 398-399).

\subsection{Type II: Formations associated with mineralisations}

Type II: Formations associated with mineralisations are mostly of hydrothermal origin. They are most frequently deposited as veins when minerals precipitate from hot aqueous fluids as they percolate through discontinuities in the rock (joints, faults, see Figure 1: 2 and Figure 3: a-d). Some syndiagenetic deposits are stratified. Iron in these mineralisation deposits is often associated with lead, zinc, silver, antinomy, barium, gold, copper, etc. (Blot 2002; Jébrak \& Marcoux 2008: 57-63, 198-203, 333-342; Kholodov et al. 2012; Rossi \& Gasquet 2014). Deposits are of limited geographical extent, measured in hundreds of metres, and geological maps do not always show their presence unless they are known to have been mined. In which case, maps tend to show the material extracted, rather than mineral composition of the ore body.

Mineralisations can form many different types of metallic body (shape and composition), including iron-lead-zinc deposits and iron oxide-copper-gold (IOCG) deposits, which are composed mostly of iron oxides and sulphides (Rossi \& Gasquet 2014). Contact metamorphism allows mineralising fluids to penetrate the surrounding wall rock to a depth of a few centimetres (Figure 1: 2). 

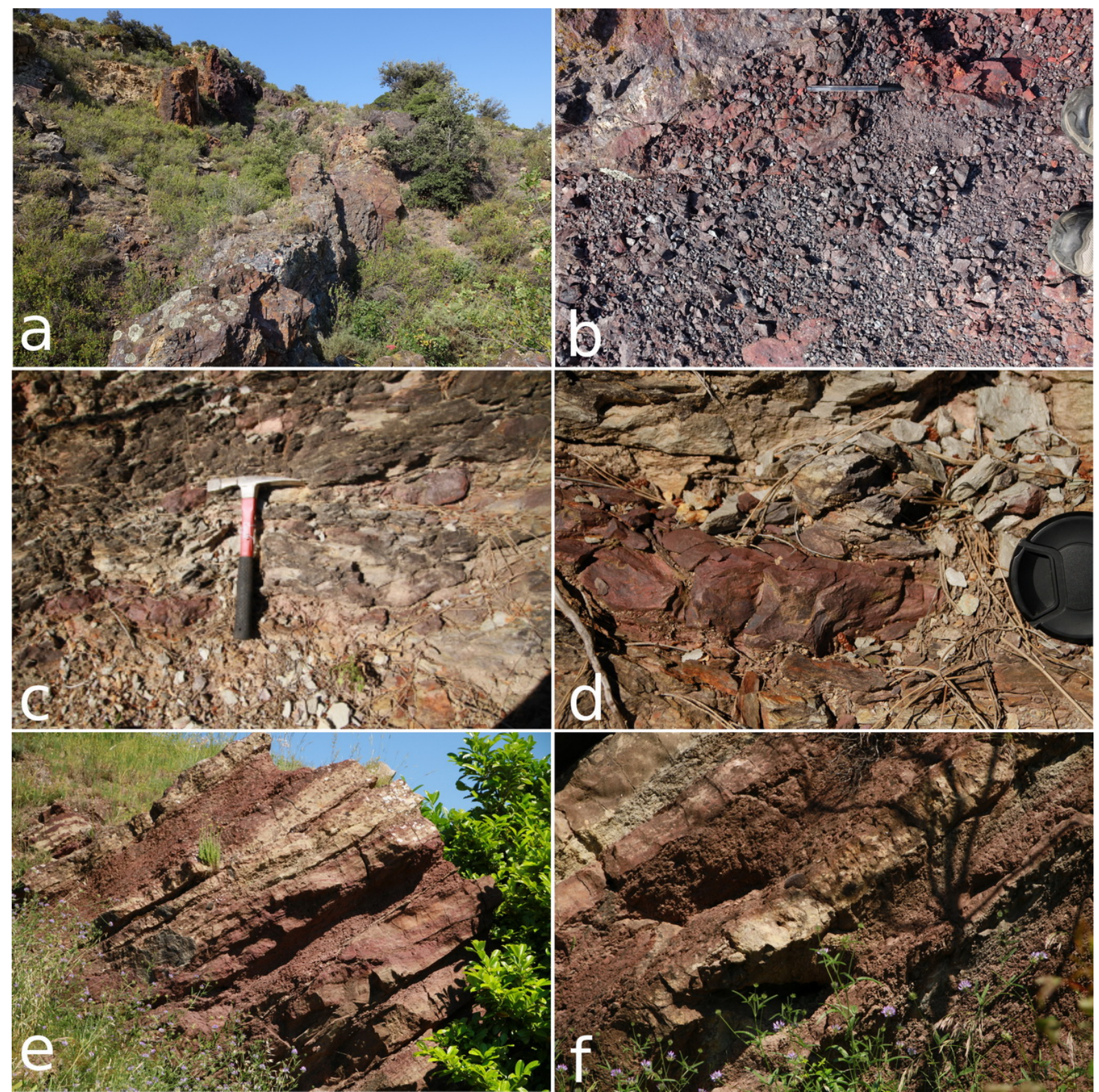

Figure 3. a-b) Hematite-quartz hydrothermal vein (contact between Upper Trias marl-gypsum and various Lower Jurassic carbonate formations), Lesquerde, Pyrénées-orientales, France, a) the metallic body measures around $500 \mathrm{~m}$ long, c-d) Hematite hydrothermal vein in arkosic sandstone (Trias), Bordezac, Gard, France, e-f) Stratiform hematite vein and metasomatism in Callovian limestone, Pierremorte, Gard, France, e) 3 m high. Photos: H. Salomon.

In addition, metasomatism, either by percolating fluids or by solid-state diffusion, can result in rocks being permeated, to a greater or lesser extent, by iron oxides, e.g., the ferruginous limestones at Pierremorte, Gard, France (Figure 1: 3 and Figure 3: e-f). Iron may be derived either from outside sources or from minerals within the surrounding rock (Jébrak \& Marcoux 2008: 46-47).

Ferruginous springs (Denayer 2011) bring to the surface mobile iron, which then oxidises and precipitates to form crusts. Bacteria contribute to the oxidation and mineralisation of iron present in high concentrations in the water (Garilli et al. 2020; Handley et al. 2010; James \& Ferris 2004; Mustoe 1981). 


\subsection{Type III: Formations containing concentrations of iron liberated by the continental weathering of pre-existing rocks}

Type III iron oxide-rich rocks are common. This transformation, outlined below, is particularly favoured by warm, humid climates (Beauvais \& Colin 1993; Kholodov et al. 2012; Triat 2010: 116-143; Widdowson 2007):

1- Leaching of soils and rocks by percolating rainwater, biological activity and hydrolysis;

2- Dissolution of iron-rich minerals (glauconite, pyrite, chlorite, phyllosilicates, etc.) and transport of the liberated iron ions;

3- Deposition, concentration and trapping of iron when Eh and $\mathrm{pH}$ conditions change due to contact with either carbonate rocks (limestone, dolomite) or different lithologies, and precipitation of iron in the form of sulphides and carbonates, which then oxidise (goethite, hematite).

These modifications give rise to formations composed of successive leached and ironenriched horizons, with iron-rich hardpans, ferricretes, duricrusts or ferricrusts, layers of iron ox(hydrox)ide-rich pisolites and lithoclasts, ferruginous-clay horizons and horizons containing fragments of weathered parent rock (Figure 4).

\section{a) Laterite}

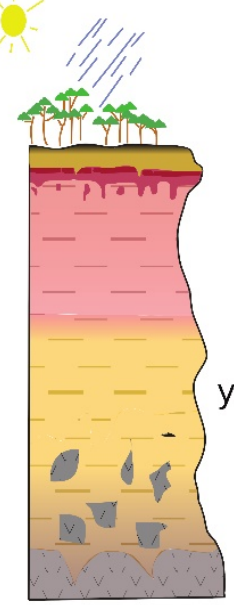

b) Ochre

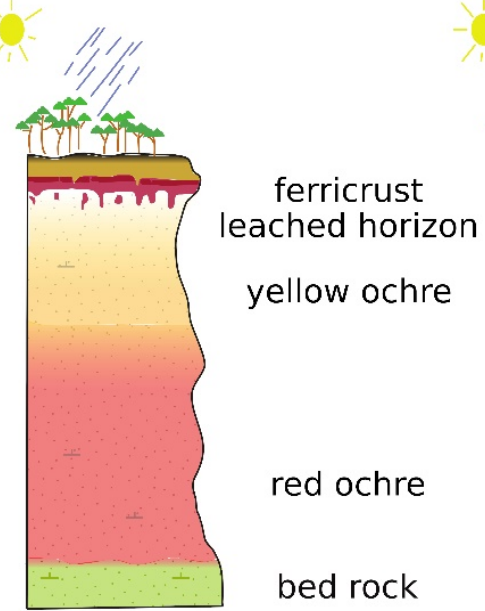

C) Bauxite

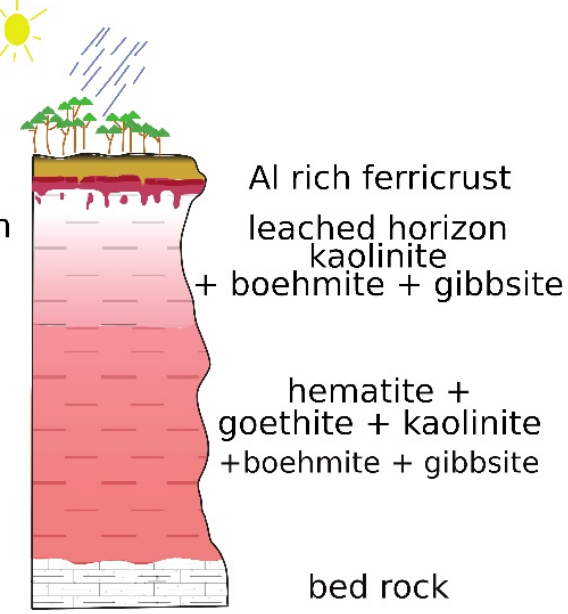

\section{Horizons}

soil goethite-rich ferricrust red laterite yellow laterite saprolite bed rock

\section{$\mp$ marl to argilaceous Fe minerals bearing volcanic rocks or peridotite}

$\square$ kaolinite-rich

$\square$ glauconite-rich

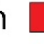
hematite-rich

Figure 4. Weathering profiles: a) Laterite, b) Ochre, c) Bauxite. Diagrams: A. Chassin de Kergommeaux (after Coquinot \& Salomon (2013); Triat 2010: 117, 123, 125, 127, 134 and 136).

\subsubsection{Type III A: Weathering profiles}

Type III A: weathering profiles (Triat 2010: fig. 10; 123) are often referred to generically as laterites, alterites or ferralitic soils (Figure 5: a-b).

- In-situ weathered horizons (alterite) (Beauvais \& Colin 1993; Gourdon-Platel et al. 2000) occur when the weathered material conserves the architecture of the parent rock. These horizons generally contain fragments of the parent rock mixed with inherited minerals, newly formed minerals, including iron ox(hydrox)ides, and various types of concretions (Lozet \& Mathieu 2002: 20). 


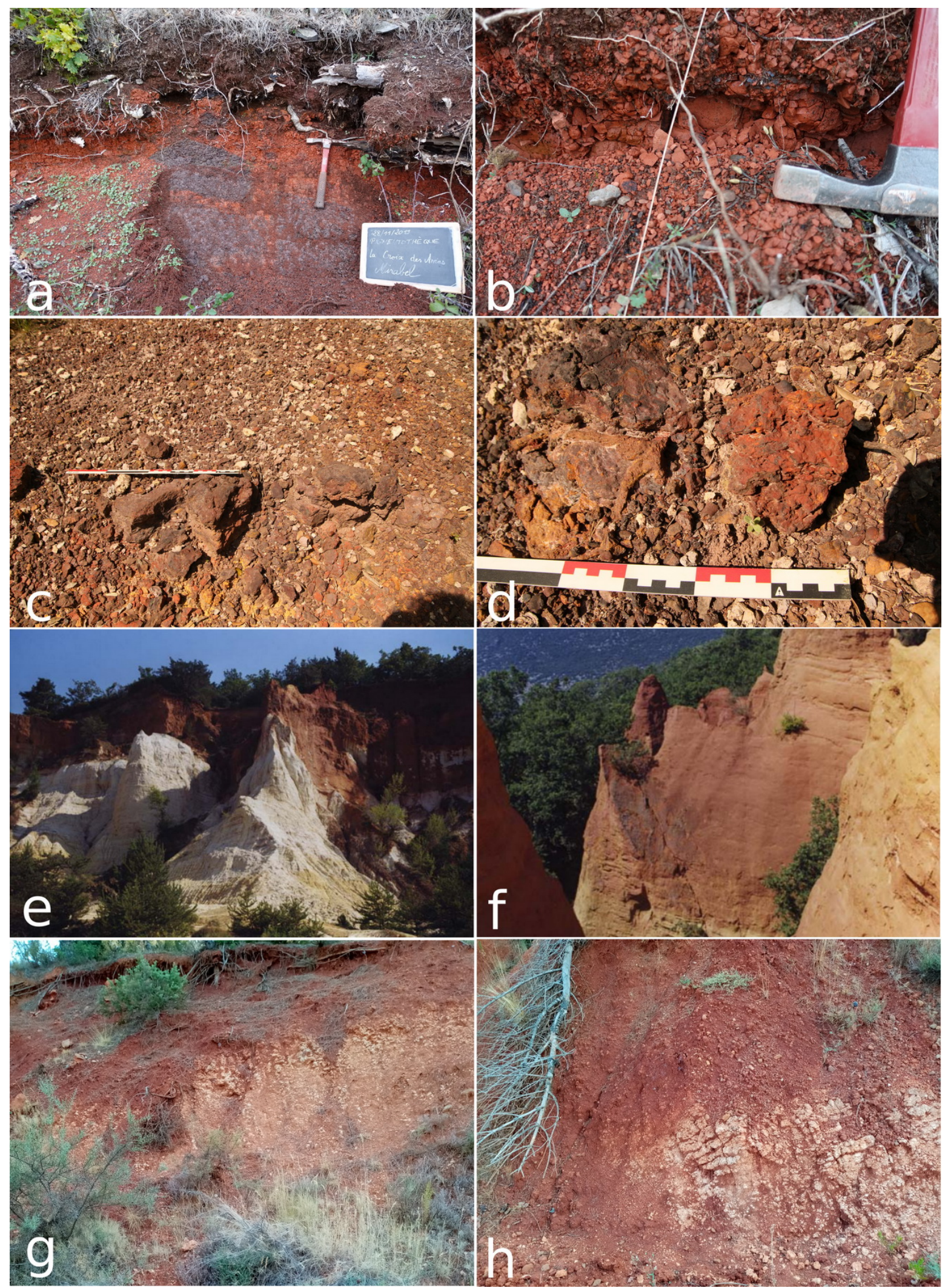

Figure 5. Iron oxide formation in weathering profiles: a-b) Palaeosol formed on basalt, Mirabel, Ardèche, France, c-d) Iron crust formed in a Middle Cenomanian sand containing kaolinite and ferruginous sandstone horizons, La Capelle-et-Masmolène, Gard, France, e-f) Ochre profile, weathered Albian-Cenomanian glauconitic sand, Roussillon, Vaucluse, France, e) top: ferricrust with underlying hematite-rich clayey sand; bottom: leached kaolinite-rich horizon, f) yellow goethite-rich and red hematite-rich horizons, g-h) Terra Rossa on Upper Gargasian-Clansayesian calcareous-marl, Maury, Pyrénées-orientales, France. Photos: H. Salomon. 
- Ferricrete, also known as iron duricrust, ferricrust or hardpan, occurs within welldeveloped weathering profiles (Figure 1: 4, Figure 4 and Figure 5: c-d) (Widdowson 2007).

- Laterite (Figure 4: a) is formed by the surface weathering of iron- and manganese-rich igneous rocks under wet tropical or equatorial conditions, which are conducive to intense chemical weathering. Lateritic soil profiles are characterised by alternating aluminium-rich (in the form of gibbsite and kaolinite) and iron-rich (in the form of iron oxides and iron hydroxides) horizons, with basal horizons containing numerous fragments of the parent rock (saprolite). Laterites subject to alternating wet and dry conditions are capped by an iron duricrust (Beauvais 1999; Beauvais \& Colin 1993; Lozet \& Mathieu 2002: 264-265; Petersen 1971; Triat 2010: 117).

- Ochres (Figure 4: b and Figure 5: e-f) are glauconitic sands or sandstones (hence of marine origin) that have been subject to continental weathering in warm, humid climates during laterization. The iron is derived mostly from the hydrolysis of glauconite into kaolinite. This weathering substantially alters the mineralogy and composition of the original rock, which becomes enriched in kaolinite (and other aluminium-rich minerals) and in iron oxides and hydroxides (Guendon \& Parron 1985; Onoratini,1985; Triat 2010: 134).

- Terra Rossa (Figure 1: 5 and Figure 5: g-h) is a rarely used term describing the red clay residues left by the dissolution of limestones and dolomites (decarbonatation), with $\mathrm{SiO}_{2}$ depletion and $\mathrm{Fe}_{2} \mathrm{O}_{3}$ enrichment. Terra Rossa forms on top of carbonate beds. This type of weathering (fersiallitisation) typically occurs in warm, sub-tropical or Mediterranean climates with variation between seasons (Lozet \& Mathieu 2002: 457).

- Iron weathering deposits in limestone (Figure 6: a) form by the direct weathering of limestone into iron-rich clay and iron crusts. They occur on the surface of the limestone or as coatings in depressions and karst cavities (Salomon \& Pomel 2005). The breccia structure is produced by weathering breaking up iron deposits that accumulated in the karst (Figure 6: a4).

- Bauxite (Figure 4: c and Figure 7: a-b) is a sedimentary or residual rock composed of ox(hydrox)ides of aluminium accompanied by iron ox(hydrox)ides, clay minerals (kaolinite) and titanium dioxide minerals. It varies in structure but is often pisolithic. Bauxite may be either autochthonous (primary), produced by in-situ lateritic weathering of the parent rock (marl, calcareous mudstone, argillaceous limestone, schist), or allochthonous (redeposited), formed by materials from ferrallitic weathering deposits that are transported downstream, redeposited, often in karsts, and subject to further weathering (Guendon \& Parron 1985; de Lapparent 1930: 176-191; Nicolas 1968; Valeton 1996: 55-182).

- Siderolithic iron or Bohnerz: the term "siderolithic" describes both a stratigraphic period (i) and a formation mode (ii): (i) a long-abandoned stratigraphic division corresponding to a period marked by strong continental weathering that was long believed to take place during the Eocene-Oligocene but, according to latest studies, can also be linked to the great late Jurassic-early Cretaceous regression (Théveniaut et al. 2007; Thiry 2011: 19-33; Thiry et al. 2005; Yans 2003), and (ii) to products of this type of weathering (lateritic duricrusts) that have been reworked to varying degrees and possibly stored in karst cavities and other sedimentary traps. They are often composed of goethite and hematite pisolites, wrapped in ferruginous clays (Gourdon-Platel \& Lambert 1986; Gourdon-Platel et al. 2000; Nicod 1996; Rosenthal 1991; Simon-Coinçon et al. 2000; Thiry et al. 2006). 


\section{a) weathering iron deposit}

1

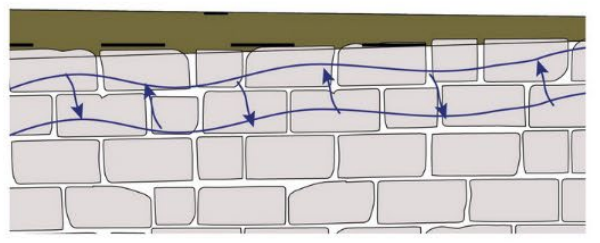

2

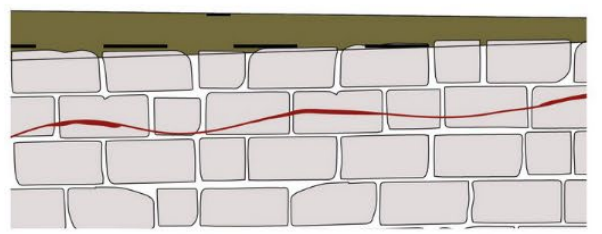

3

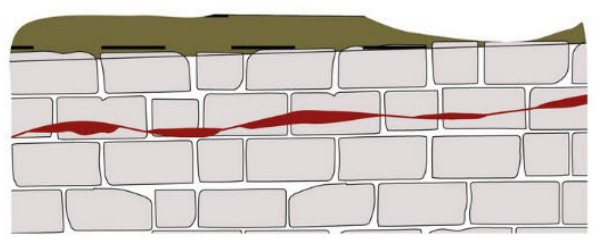

4

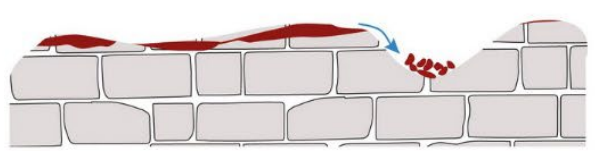

\section{b) cryptokarstic formation}

1

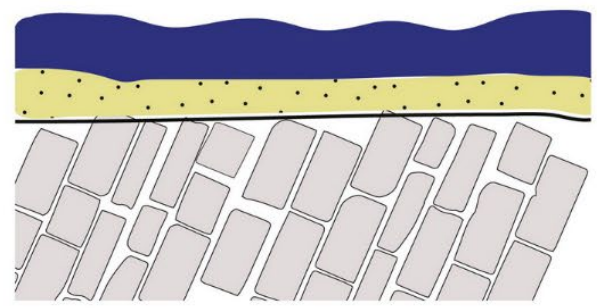

2

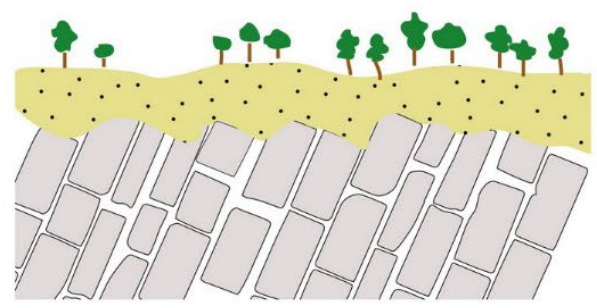

3

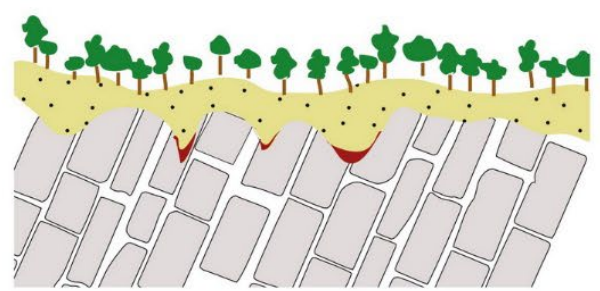

4

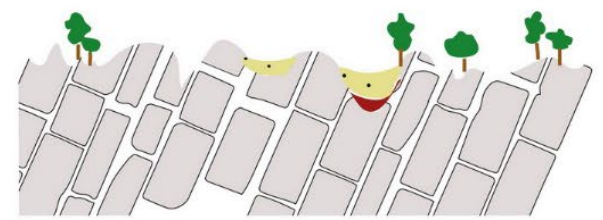

marl

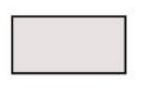

limestone

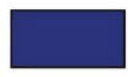

sea

\section{$\because \therefore$ glauconitic sandstone}

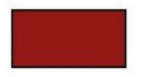

iron-rich formation

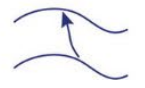

piezometric level

Figure 6. Formation of a) Iron weathering deposits in karst: 1-2) Direct weathering of limestone to iron-rich clay minerals, 3) Leaching and precipitation of iron at strata surfaces or in karsts, 4) Erosion of upper strata and iron precipitation and accumulation in karst depressions; b) Cryptokarstic iron deposits: 1) Glauconite-rich sand deposit over older limestone strata, 2) Growth of tropical vegetation - leaching of iron by percolating acidic waters, limestone weathering and cryptokarst formation, 3) Humid, tropical climates accelerate karstification and iron precipitation at the contact between sandstone and limestone, 4) Quaternary erosion and weathering of iron formations. Diagram: A. Chassin de Kergommeaux (after Quinif 1993). 

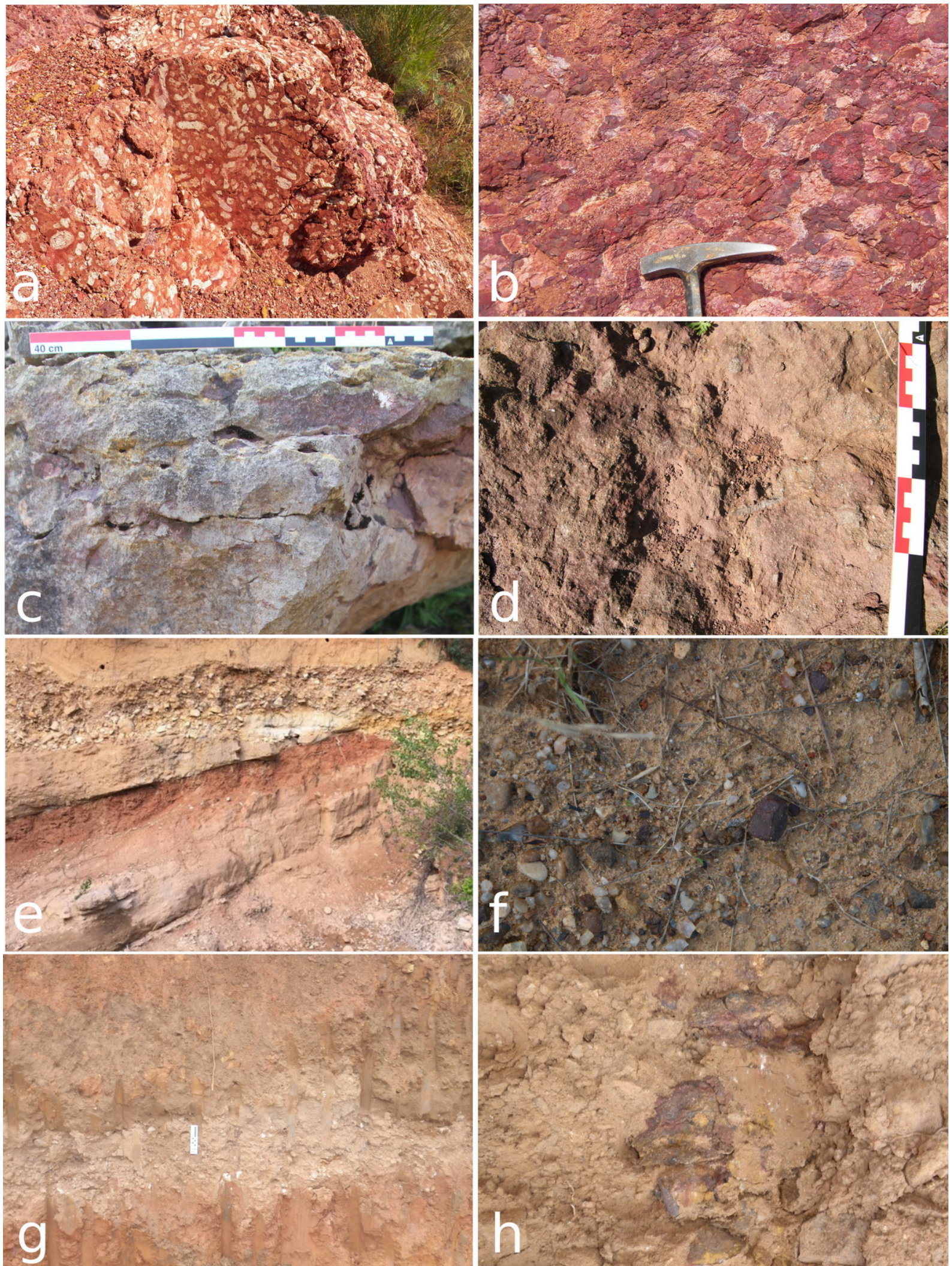

Figure 7. a-b) Allochthonous bauxite trapped in a Middle Jurassic karst, Cazouls-lès-Béziers, Hérault, France, cd) Ferruginised limestone, Aalenian, La Rousse, Ardèche, France, e-f) Alluvial iron-oxide-rich pebbles in recent and Cretaceous alluviums, Vagnas, Ardèche, France, g-h) Colluvium with fragments of Eocene lateritic crust, Cussac, Périgord, France, g) white scale bar: $20 \mathrm{~cm}$, h) pebbles measures around $5 \mathrm{~cm}$. Photos: H. Salomon. 


\subsubsection{Type III B: Weathered mineralisation deposits}

Gossan, also called iron cap (Figure 1: 6), is the oxidized cap of a mineral vein or ore deposit with $\mathrm{Fe}, \mathrm{Pb}, \mathrm{Zn}, \mathrm{Cu}$ sulphides. Weathering of a sulphide body produces iron ox(hydrox)ides and segregation of leached elements, creating a characteristic cementation zone. Remarkable textures of sulphides replacement are often seen in the form of boxworks: honeycomb patterns of a mixture of hydrous iron and manganese oxide minerals that remains in the cavity after a sulphide mineral has dissolved. Their colour varies according to their mineral composition: Fe-ox(hydrox)ides (brown to red), Mn-ox(hydrox)ides (black), Cucarbonates and sulphates (blue-green)(Blot 2004; Haldar 2018; Jébrak \& Marcoux 2008: 475484; Kholodov et al. 2012; Rossi \& Gasquet 2014).

\subsubsection{Type III C: Iron deposits formed by trapping}

- Cryptokarstic deposits form when materials weathered in wet tropical climates (mostly weathered glauconite sands) accumulate in karst cavities (Figure 6: b). Percolating waters not only attack the limestone, accelerating karstification under vegetal cover, they also leach iron from glauconite in overlying sands, which is then redeposited as a coating or crust at the limestone-sand contact (Quinif 1993; Salomon \& Pomel 2005).

- Strata-bound replacement iron mineralisation (after Routhier 1963: 700-704) is an old expression. It occurs when goethite and iron hydroxide minerals showing various degrees of hydration and released by the weathering of overlying sediments precipitate at the contact between strata of different lithologies (e.g., limestone and shale), following a bedding plane (Figure 1: 8).

\subsection{Other deposits formed by a combination of diagenesis, alteration and weathering}

- Lahn Dill is a type of iron ore consisting mostly of hematite and quartz that was first described in the Dill and Lahn Valleys in Germany (several occurrences are also present in Central Europe as in the Renan massif, Harz, Eastern Thuringia and in the Eastern Sudets). It is produced by a combination of volcano-sedimentary deposition, diagenetis, and late hydrothermalism (Flick \& Nesbor 1988; Flick et al. 1990; Nesbor 2007).

- Ferruginous and ferruginised limestones are limestones (Figure 7: c-d) in which the original calcite was partly or entirely replaced by iron ox(hydrox)ides during sedimentation or diagenesis, or as a result of hydrothermal injection, e.g., the Hettangian crinoidal limestones of Thoste (Boirat et al. 1980; Cayeux 1909: 7-33; Salomon 2019).

- Ferruginous hardgrounds (Figure 1: 9) are iron and manganese-rich crusts that form on top of, and cover all or part of, a carbonate layer when sedimentation slows greatly or stops, thereby allowing the sediment to lithify before subsequent beds are deposited. Intense chemical and biogenic weathering leads to the precipitation of iron and manganese ox(hydrox)ide. Hardgrounds may also contain traces of biological activity (Préat et al. 1999).

- Alluvial (Figure 1: 10 and Figure 7: e-f) and colluvial (Figure 1: 11 and Figure 7: g-h) deposits are large accumulations of allochthonous material, with grains up to the size of pebbles and cobbles, transported by flowing water (alluvium) or gravity (colluvium). Alluvial deposits contain rounded concretions, pebbles and cobbles which may be cemented into puddingstone (Figure 8: a). Colluvial deposits consist of angular to sub-rounded fragments and concretions (Figure 8: b) that accumulate at the foot of slopes or on gently sloping hillsides to form layers of intermittent extent and variable thickness (Denayer 2011: 37).

The rocks and minerals formed in the settings described above may then be highly modified by further weathering (Figures 1 and 8: c-d). 

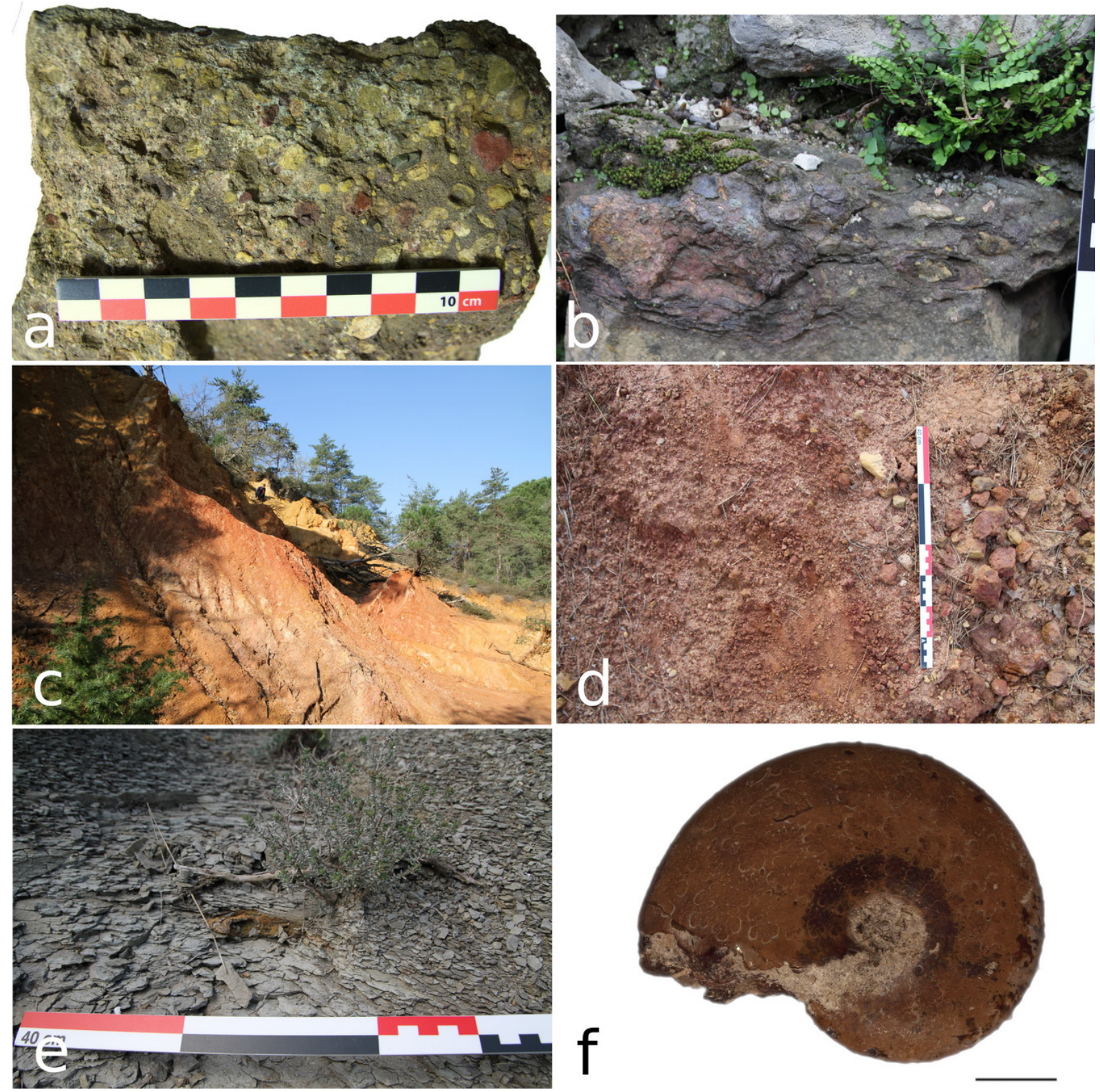

Figure 8. a) Puddingstone with pebbles of hematite and goethite, Campanian, La Moulinette, Hérault, France, b) $10 \mathrm{~cm}$ iron oxide-rich concretion, Les Vans, Ardèche, France, c-d) Weathering profile of a Lower Eocene fluviolacustrine sequence: ferruginous sand and sandstone, vallon de Fougeras, Dions, Gard, France, c) the outcrop is about $10 \mathrm{~m}$ high, e-f) Iron ox(hydrox)ide containing fossils derived from pyritised ammonites in liassic marls, Les Assions, Ardèche, France, e) ferruginous ammonite in marl deposits, f) isolated ferruginous ammonite (scale bar: 2 mm). Photos: a-e) H. Salomon, f) A. Chassin de Kergommeaux \& H. Salomon.

\subsection{Deposits rich in non-oxidised iron and magnetite}

Deposits in which iron-rich minerals occur mostly in the form of iron sulphides (pyrite, marcasite, mispickel, see Figure 8: e-f), sulphates (jarosite), carbonates (siderite), phosphates (vivianite) or silicates (chlorites, glauconite) are more or less (glauconite, jarosite), even nonpigmentaceous. However, they may contain some pigmentaceous matter due to weathering and heating partially oxidising these minerals into hematite and goethite. Black magnetite may also oxidise into hematite. 


\section{The Pigmentothèque}

In order to catalogue both this genetic diversity and the vertical and horizontal variability within deposits and geological formations, it is necessary to put in place a sampling strategy suited to each situation. Analyses of the samples collected, including their physical and chemical properties, and assessments of their accessibility, reveal the myriad types of potential resources and provide data that can be used to decipher the criteria that guided prehistoric humans' choices of raw materials, which were governed by the availability of different resources and their intended use (Pradeau et al. 2016; Salomon 2019).

With this in mind, at the beginning of the 2000s several researchers began cataloguing deposits capable of supplying the types of colouring matter used at Palaeolithic rock art sites near the Ardèche River (N. Aujoulat, J. Monney). The Pigmentothèque was set up in 2016 to extend the area covered by this work and to further systematize the collection and analysis of samples. This Collective Research Project combines a research programme to develop and apply investigative methods and apps with a resource centre that houses data (photographs, measurements, quantifications, standardised descriptions), identification keys and collections of samples (both unprocessed and prepared) that can be used to answer questions about the colouring matter used in the past. The Pigmentothèque has also built up a database of the physical characteristics of rocks (including criteria that make a material exploitable, such as its mechanical properties, appearance, texture, etc.) for use in experimental and functional studies. The methodology developed by the Pigmentothèque is based on experience gained by the "Réseau de Lithothèques" interdisciplinary Collective Research Project (Delvigne et al. 2020; Fernandes 2015; Fernandes et al. 2019; Tuffery et al. 2019) and existing methodologies for studying archaeological colouring matter (see Chalmin \& Salomon 2019; Chalmin et al. 2021a; Salomon et al. 2019, for detailed methodology and vocabulary).

\subsection{Prospection: collecting information in the field}

Possible sampling sites are identified by combining information contained in the French Bureau of Geological and Mineralogical Research's (BGRM) archives with other sources of information, such as place names and satellite and aerial photographs taken at different periods (infoterre.brgm.fr, remonterletemps.ign.fr).

An app and field datasheets originally created for silicites (Chalmin et al. 2021a; Delvigne et al. 2020; Salomon et al. 2019; Tuffery et al. 2018; 2019) have been adapted to the needs of research on iron- and manganese-rich materials, which occur in a wide range of geological settings and lithologies. (The step-by-step documentation of the sampling spots are detailed in Salomon et al. (2019) and Chalmin et al. (2021a), were the attributes used with the app in the field and the definitions for each attribute are presented). Initial studies of the sources of raw materials used as colouring matter involved inspecting and describing fresh and weathered samples collected in the field, while checking parameters relating to each resource's origin and stratigraphic position (stratigraphy, site effects, patina, geomorphology, geological and mining documents) (Delvigne et al. 2020).

\subsection{Methods for characterizing colouring materials}

The Pigmentothèque houses samples in the form of unmodified cohesive blocks, prepared blocks (polished sections and thin sections) and powders that can be subjected to petrographic, mineralogical, chemical and geochemical analyses (see available list and descriptions in Chalmin et al. 2021a; b; Chassin de Kergommeaux et al. 2021; Salomon et al. 2019). 


\subsubsection{Visual examinations on different scales}

Following an iterative description at different scales from surface to volume enables to replace in a chronology the different characteristics (stigmata and compositions) inherited and acquired by the colouring matter during specific events of its "evolutive chain" (as proposed by Fernandes (2012: 172) and Delvigne et al. (2020)) (Figure 9):

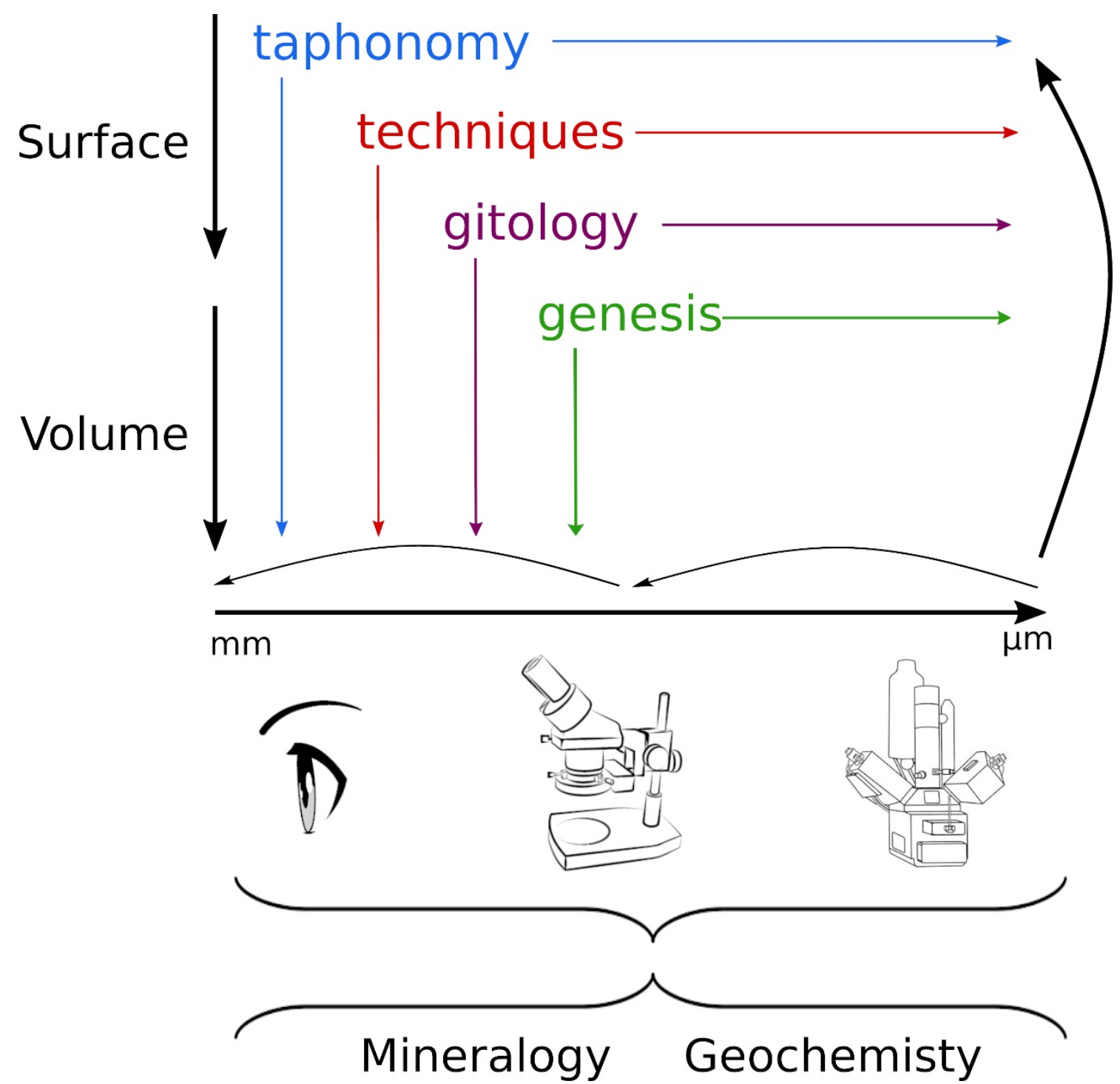

Figure 9. Diagram summarising the methodological approach to access the multiple signatures of colouring matter. Diagram: H. Salomon.

- genesis: Intrinsic characteristics of the materials reveal their formation context: grains and other clasts, binding phases (cement and matrix), primary mineral assemblage, texture, etc.

- gitology: examination of the stigmata due to weathering and transport of the raw material prior to its collection give clues on the geomorphological location of the procurement.

- human modifications (techniques): techniques implemented in the past to transform the raw material such as separation, heating, powder production, mixing with other substances leave recognisable stigmata on and within the colouring matter (Figure 10).

- taphonomy: post-depositional modification of the colouring matter is marked by addition and loss of compounds and matter (Figure 10). 


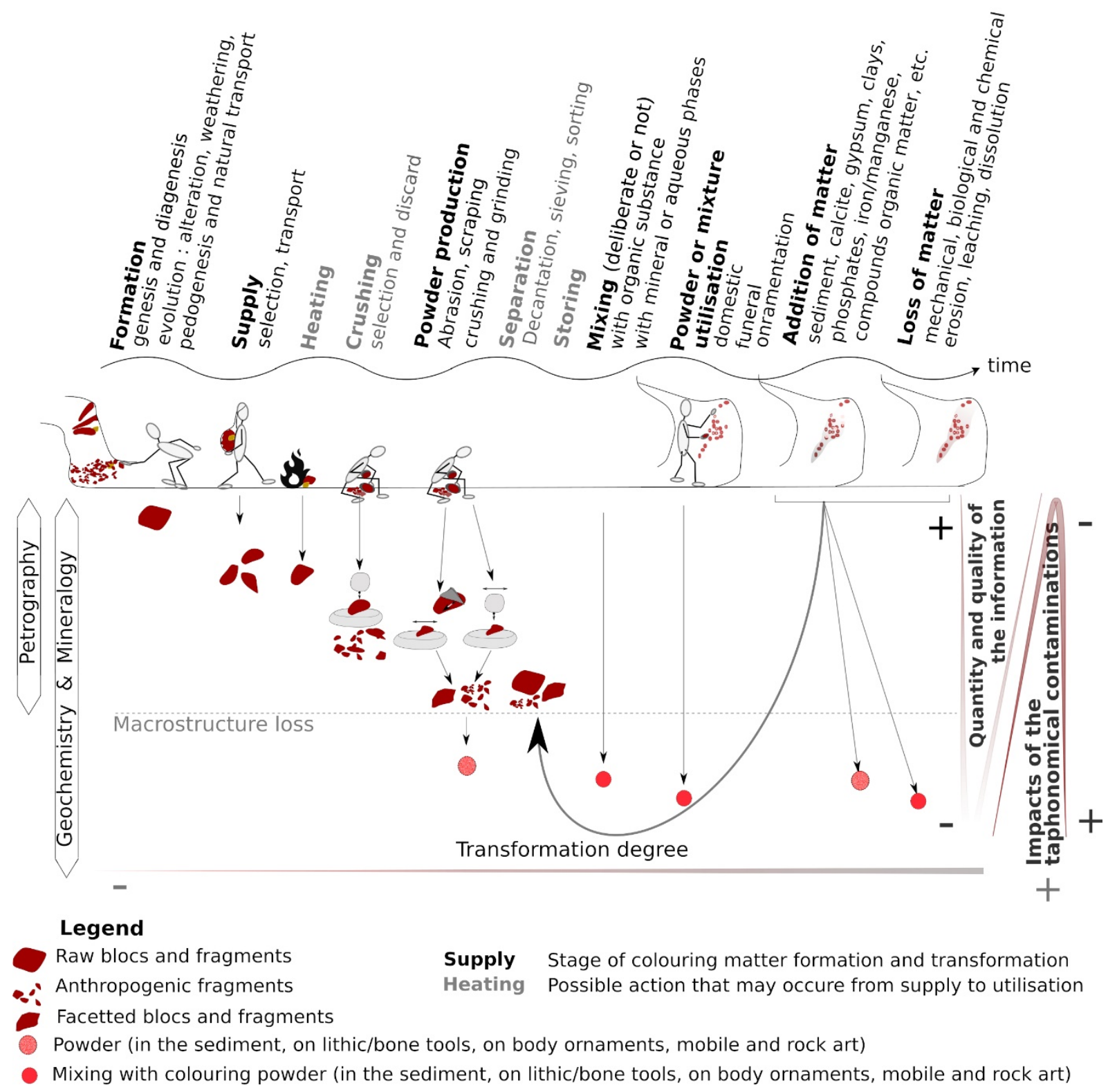

Figure 10. Diagram summarising the different trajectories followed by colouring matter from its source to its use and conservation, and involving different degrees of transformation. The amount of information about the material that is lost correlates with the degree of transformation. Diagram: H. Salomon.

Lithological, petrographic, mineralogical (nature and association of minerals within the rock, degree of crystallinity) and geochemical (proportions of major, minor and trace elements) analyses are used to determine a signature for each formation, bed, horizon, or outcrop rich in iron or manganese ox(hydrox)ides and recorded in standardised description sheets (Chalmin et al. 2021a; Salomon et al. 2019). In addition, experience has shown the importance of first describing each sample's mesoscopic characteristics (x10 to x150). Indeed, the first things prehistoric humans would have noticed about a rock, mineral, soil or weathering profile would have been its visual and tactile properties (colour(s), hardness, compactness, homogeneity/heterogeneity, colouring power). Preparing these descriptions is a simple procedure that can be used to document and analyse large archaeological collections in their entirety (Billard et al. 2016: 17-20, 221-226; Chalmin et al. 2021a; Dreesen et al. 2016; Pradeau 2015; Pradeau et al. 2016; Salomon 2009; 2019; Salomon et al. 2014; 2019). 
All types of rock and colouring and coloured archaeological remains should be inspected visually - naked eye, stereomicroscope, polarising (transmitted and reflected) microscope, scanning electron microscope - as these analyses provide information on weathering of rocks and minerals both before, they were collected and after they were used. They also guide subsequent chemical and geochemical analyses, whether conducted on the object as a whole or on selected parts. Geological samples are categorised according to criteria set out in classification tables (e.g., Choquette \& Pray 1970; Cojan \& Renard 1999: 192-197, 402; Dott 1964; Dunham 1962; Folk 1959; Lundegard \& Samuels 1980; Mount 1985; Pettijohn 1975: 543; Pettijohn et al. 1987; Prothero \& Schwab 2014 :498; Udden 1914; Wentworth 1922), which enable most of the intrinsic quantitative and qualitative characteristics of colouring matter to be described (Chassin de Kergommeaux et al. 2021): the detail routine of macro- to microscopic description accompanied by the common vocabulary (in English and French), definitions (only in French for the moment), as well as qualitative and quantitative charts may be found in Salomon et al. (2019) and Chalmin et al. (2021a).

\subsubsection{Chemical analyses}

Complementary to petrographical determinations, elemental and structural analyses may give additional clues for cohesive colouring matter provenance (Beck et al. 2012; Chalmin et al. 2021b; Dayet 2021; Dayet et al. 2015; 2017; Goemaere et al. 2016b; c; MacDonald et al. 2018; Mathis et al. 2014; Mauran et al. 2021; Popelka-Filcoff et al. 2008; Salomon et al. 2016). X-ray diffraction provides semi-quantitative analyses that indicate the presence or absence of certain crystalline phases and their approximate relative abundance. Most elemental analyses of Pigmentothèque samples are carried out by proton induced X-ray emission ( $\mu$ PIXE) spectrometry and inductively coupled plasma (ICP) spectrometry, as these two methods have satisfactory detection limits (unlike portable X-ray fluorescence, which is commonly used in archaeometry) (Chanteraud et al. 2021). We systematically use the six geological internal "standards" presented in PCR Pigmentothèque's reports. They were selected for their singular petrophysical and geochemical characteristics in order to compare analytical settings and campaigns, as well as measures obtained on diver sample types: cohesive non prepared blocks and fragments, patinated surfaces and fresh breaks, sections, homogenised powder, applied powder and micro-samples (Chalmin et al. 2021a; Chanteraud 2020: 96-106; Chanteraud et al. 2021; Chassin de Kergommeaux et al. 2021; Salomon et al. 2019).

These analysis methods are suitable for any specimen of geological colouring matter and a selection of archaeological objects, but non-invasive investigations are privileged for these latest. The set of analyses can be used to determine a geochemical signature that is linked to how the raw material formed and how it has transformed over time (Ambrosi \& Nahon 1986; Beauvais 1999; Byrne \& Kim 1990; Dill 1985; Dupuis \& Beaudouin 2011; Green \& Watling 2007; McQueen 2005; Monteiro et al. 2018; Zipkin et al. 2017). Therefore, it seems crucial to implement analytical methods that are sufficiently relevant, sensitive and precise to identify significant chemical signatures in relation to resources that may have been sought and exploited (Beck et al. 2012; Dayet 2021; Dayet et al. 2015; MacDonald et al. 2018; Mathis et al. 2014; Popelka-Filcoff et al. 2007; Salomon et al. 2016). In addition, we argue that these analyses make sense through an iterative approach (Figure 9). Nonetheless, colouring matter applied to an object is most frequently in powdered form, so it cannot be subject to petrographic analysis. In such cases, the chemical composition of colouring matter samples has to be compared with that of reference samples taking into consideration the very small quantities of colouring matter in residues and paintings and the environmental input (rock, sediments, post-depositional concretions and coatings, leaching and erosion) (Chanteraud et 
al. 2021). With these numerous anthropogenic and post-depositional modifications, being able to systematically identify the type of geological formation from which a sample of powdered colouring matter was obtained is an obstacle that has rarely been overcome (Eiselt et al. 2011; Lebon et al. 2014). This is why we currently combine detailed, standardised descriptions of archaeological raw materials with chemical analyses conducted using standardised protocols, which we compare with appropriate reference samples (see for instance geochemical analysis presented in Chalmin et al. 2021a; Chanteraud 2020: 146-189; Salomon et al. 2019).

\section{Conclusion}

The general analytical methodology developed by the Pigmentothèque for studying archaeological collections is based on the need to determine the transformations a material has undergone, whether before collection by its prehistoric user, during its use or after it was discarded. Because these modifications destroy many of the raw material's original properties, it is essential to identify them in order to determine the material's fundamental signature and thereby ascertain its geological and geomorphological origin. As Figures 1 and 10 show, pigmentaceous rocks and minerals may be primary deposits, which are subject to transformations by circulating fluids and leaching. Erosion may also result in primary deposits being transported (by gravity, by runoff, etc.) and deposited in a new environment to form secondary deposits, where they are again weathered. After being collected by prehistoric humans, they may have been heated, ground into powders, separated, mixed with other substances and applied to different substrates. Leaching, erosion, capping and encrustation continue to modify these materials on rock walls and in sediments. Hence, the first step in retracing circulation networks and prehistoric supply strategies is to identify the different characteristics materials acquired as they evolved (Delvigne et al. 2020; Fernandes 2012: 22, 122-124). The fundamentals presented in this paper should be followed by other papers reporting examples illustrated at different scales, from the outcrop to the microscopic scale. Comparisons of chemical compositions can thus be based on the reality of these materials, taking into account the variability of the lithologies present within an outcrop or a formation and individualising the petrographic, mineralogical and geochemical signatures most likely to allow comparisons with archaeological remains (Chalmin et al. 2021a; b; Chanteraud 2020: 146-189).

Although ascertaining the geological and geographical provenance of colouring matter can throw light on geological knowledge and technological skills that are now lost, the processing of colouring matter to enable its use and the small quantities preserved make this endeavour extremely complex. Nevertheless, the wide diversity of lithologies from which these materials were obtained (formation and facies), each with its distinct petrographic, chemical and mechanical properties, makes it possible to recognise the criteria governing past choices and to relate these choices to cultural and economic factors, which were themselves conditioned by a combination of the material's intended use and technological possibilities. These past knowledge and preferences may then be replaced in a chronological framework and spatial envelope.

Moreover, recourse to iron-rich pigmentaceous materials was not restricted to the Palaeolithic; their use has continued throughout history. Hence, the Pigmentothèque is also a valuable resource for scholars investigations focusing on more recent periods (Mesolithic, Neolithic, Bronze and Iron Ages, Antiquity, Middle Age, etc.), or on different geographical areas, studies of mural and easel paintings, and work to restore and create replicas of heritage objects and sites. 


\section{Acknowledgement}

This program takes advantage of the financial and scientific support of the AuvergneRhône-Alpes Regional Council Department of Cultural Affairs (France). We would like to thank K. Gernigon, Regional Curator of Archaeology, for his scientific support. Our thanks also go to L. Devillard for the administrative management and to the AVDPA for the management of the credits. We would like to thank the University of Savoie-Mont-Blanc for its financial support (MASCARA and TRAnSFeRT projects) and the ASTRE platform for access to measuring instruments (DRX, MEB-EDS). Our many thanks are also due to professional and non-professional contributors who showed us geological outcrops, discussed the methods and helped systematizing the records of geological samples. Finally, we owe sincere thanks to the two reviewers who, through their comments, advises and questions, helped to improve this article.

\section{Data accessibility statement}

The data used here are from the ownership of the authors, and the others are cited. Reviewed annual reports of the Pigmentothèque project are available online in open access at the open archive HAL (repository of scholarly documents from all academic fields): https://hal.archives-ouvertes.fr/.

Access to the geological references for purposes of research must be arranged with E. Chalmin and H. Salomon.

Spectroscopic references are available in open access on SSHADE (OSUG Data Center). https://www.sshade.eu/db/pig. doi:https://doi.org/10.26302/SSHADE/PIG

\section{References}

Ambrosi, J. P. \& Nahon, D. 1986, Petrological and geochemical differentiation of lateritic iron crust profiles. Chemical Geology, 57(3-4): 371-393. doi:10.1016/00092541(86)90059-8

Aubry, T. 2005, Étude de l'approvisionnement en matières premières lithiques d'ensembles archéologiques. Remarques méthodologiques et terminologiques. In: Comportements des hommes du Paléolithique moyen et supérieur en Europe: territoires et milieux. Proceedings of the Colloque du G.D.R. 1945 du CNRS, Paris, 8-10 janvier 2003 (Vialou, D., Renault-Miskovsky, J. \& Patou-Mathis, M., Eds.), ERAUL 111, Liège: p. 87-99. (in French) ("Study of the supply of lithic raw materials of archaeological assemblages. Methodological and terminological remarks”)

Audouin, F. \& Plisson, H. 1982, Les ocres et leurs témoins au Paléolithique en France: enquête et expériences sur leur validité archéologique. Cahiers du Centre de recherches préhistoriques, 8: 33-80. (in French) ("Ochres and their evidence in the Palaeolithic in France: Investigation and experiments on their archaeological validity”)

Audra, P., Bigot, J. Y., Camus, H., Gauchon, C. \& Wienin, M. 2011, La grotte-mine du Piei (Lagnes, Vaucluse), paléokarst hypogène à remplissage de minerai de fer oxydé. Karstologia, 58(1): 1-14. (in French) ("The Piei cave-mine (Lagnes, Vaucluse), hypogenous paleokarst with oxidised iron ore filling”)

Bar-Yosef-Mayer, D., Vandermeersch, B. \& Bar-Yosef, O. 2009, Shells and ochre in Middle Paleolithic Qafzeh Cave, Israel: Indications for modern behavior. Journal of Human Evolution, 56(3): 307-314. doi:10.1016/j.jhevol.2008.10.005 
Beauvais, A. 1999, Geochemical balance of lateritization processes and climatic signatures in weathering profiles overlain by ferricretes in central Africa. Geochimica et Cosmochimica Acta, 63(23): 3939-3957. doi:10.1016/S0016-7037(99)00173-8

Beauvais, A. \& Colin, F. 1993, Formation and transformation processes of iron duricrust systems in tropical humid environment. Chemical Geology, 106: 77-101. doi:10.1016/0009-2541(93)90167-H

Beck, L., Salomon, H., Lahlil, S., Lebon, M., Odin, G., Coquinot, Y. \& Pichon L. 2012, Nondestructive provenance differentiation of prehistoric pigments by external PIXE. Nuclear Instruments and Methods in Physics Research Section B: Beam Interactions with Materials and Atoms, 273: 173-177. doi:10.1016/j.nimb.2011.07.068

Beyries, S. \& Inizan, M.-L. 1982, Typologie, ocre, fonction. In: Tailler! Pourquoi faire: Préhistoire et technologie lithique II, Recent Progress in Microwear Studies. Studia Praehistorica Belgica, Vol 2, Leuven: p. 313-322. (in French) (“Typology, ochre, fonction")

Beyries, S. \& Walter, P. 1996, Racloirs et colorants à Combe-Grenal. Le problème de la retouche Quina. Quaternaria nova, 6: 167-187. (in French) ("Scrapers and Colorants in Combe-Grenal. The problem of Quina retouch”)

Billard, C., Bosquet, D., Dreesen, R., Goemaere, É., Hamon, C., Jadin, I., Salomon, H. \& Savary, X. (Eds.) 2016, About haematite. Procurement and transformation during Recent Prehistory. Proceedings of the international Round Table, 7-8/02/2013, Namur (Jambes), Anthropologica et Praehistorica Vol. 125 \& 126. Societe Royale Belge d'Anthropologie et de Prehistoire, Bruxelles, 2 vol., 472 p.

Binford, L.R. 1979, Organization and formation processes: Looking at curated technologies. Journal of anthropological research, 35(3): 255-273.

URL: http://www.jstor.org/stable/3629902

Binford, L.R. 1980, Willow smoke and dog's tails: Hunter-gatherer settlement systems and archaeological site formation. American Antiquity, 45(1): 4-20. doi:10.2307/279653

Blot, A. 2002, Signification des ferruginisations des formations néoprotérozoïques du NordBurkina Faso (Afrique de l'Ouest). Comptes Rendus Geoscience, 334(12): 909-915. (in French) ("Significance of the ferruginisations of the neoproterozoïc formations of northern Burkina Faso (West Africa)”) doi:10.1016/S1631-0713(02)01833-3

Blot, A. 2004, Caractérisation des chapeaux de fer en milieu latéritique cuirassé. Comptes Rendus Geoscience, 336(16): 1473-1480. (in French) ("Characterisation of iron caps in a lateritic environment”) doi:10.1016/j.crte.2004.07.008

Boirat, J-M., Lhegu, J., Touray, J.-C. \& Soulé de Lafont, D. 1980, Nouvelles observations sur le gisement stratiforme de fluorine et barytine de Courcelle-Frémoy (Morvan, France). Compte rendu Académie des Sciences, Paris, 291: 5-8. (in French) ("New observations on the stratiform fluorite and barite deposit of Courcelle-Frémoy (Morvan, France)”)

Bon, F. 2009, Préhistoire. La fabrique de l'homme. L'univers historique, Seuil, Paris, 349 p. (in French) ("Prehistory. The making of man”)

Bourdier, C. 2013, Rock art and social geography in the Upper Paleolithic. Contribution to the socio-cultural function of the Roc-aux-Sorciers rock-shelter (Angles-sur-l’Anglin, France) from the viewpoint of its sculpted frieze. Journal of Anthropological Archaeology, 32: 368-382. doi:10.1016/j.jaa.2013.05.005 
Brooks, A.S., Yellen, J.E., Potts, R., Behrensmeyer, A.K., Deino, A.L., Leslie, D.E., Ambrose, S.H., Ferguson, J.R., d’Errico, F., Zipkin, A.M., Whittaker, S., Post, S., Veatch, E.G., Foecke, K. \& Clark, J.B. 2018, Long-distance stone transport and pigment use in the earliest Middle Stone Age. Science, 360(6384): 90-94. doi:10.1126/science.aao2646

Byrne, R.H. \& Kim, K.H. 1990, Rare earth element scavenging in seawater. Geochimica et Cosmochimica Acta, 54: 2645-2656. doi:10.1016/0016-7037(90)90002-3

Cabrera-Garrido, J.M. 1978, Les matériaux des peintures de la grotte d'Altamira. In: ICOM Committee for Conservation. 5th Triennial Meeting, Zagreb, 1-8 Oct. 1978: p. 1-9. (in French) ("The painting materials at Altamira cave")

Cavallo, G., Fontana, F., Gialanella, S., Gonzato, F., Riccardi, M. P., Zorzin, R. \& Peresani, M. 2018, Heat Treatment of Mineral Pigment During the Upper Palaeolithic in North-East Italy. Archaeometry, 60(5): 1045-1061. doi:10.1111/arcm.12360

Cavallo, G., Fontana, F., Gonzato, F., Guerreschi, A., Riccardi M.P., Sardelli, G. \& Zorzin, R. 2017, Sourcing and processing of ochre during the late upper Palaeolithic at Tagliente rock-shelter (NE Italy) based on conventional X-ray powder diffraction analysis. Archaeological and Anthropological Sciences, 9: 763-775. doi:10.1007/s12520-0150299-3

Cayeux, L. 1909, Les minerais de fer oolithique de France. Fascicule 2: minerais de fer secondaire. Études de gîtes minéraux de la France. Ministère des travaux publics, Imprimerie nationale, Paris, 1051 p. (in French) ("The oolitic iron ores of France. Part 2: secondary iron ores”)

URL: https://gallica.bnf.fr/ark:/12148/bpt6k62260960.texteImage

Chalmin, E. 2003, Caractérisations des oxydes de manganèse et usage des pigments noirs au Paléolithique supérieur. PhD thesis, thesis no. NNT: 2003MARN0177, HAL Id: tel00120355 at the Department of geomaterials, Marne-La-Vallée University, Marne-LaVallée, 382 p. (in French) ("Characterisation of manganese oxides and use of black pigments in the Upper Palaeolithic”) URL: https://tel.archives-ouvertes.fr/tel-00120355

Chalmin, E. \& Salomon, H. 2019, SSHADE/PIG: Pigmentothèque. SSHADE (OSUG Data Center). Service/Database. Retreived: 2021-11-13. URL: https://www.sshade.eu/db/pig

Chalmin, E., Salomon, H., Chanteraud, C., Chassin de Kergommeaux, A., Schmitt, B., Delvigne, V., Develle-Vincent, A.-L., Dubreuil, O., Fernandes, P., Gasquet, D., Genuite, K., Goemaere, É., Lemasson, Q., Pacheco, C., Pichon, L., Pignol, C., Rossi, M., Soufi, F. \& Tuffery, C. 2021, Constitution d'une "pigmentothèque": un outil pour comprendre l'approvisionnement en matériaux colorants durant la Préhistoire: rapport intermédiaire 2020. (Rapport de recherche). DRAC/SRA (Directions Régionales des Affaires Culturelles / Service Régional d’Archéologie) Auvergne Rhône Alpes p. 369; Accessed: 2021-03-05. (in French) ("Constitution of a "pigment library": A tool to understand the supply of coloring materials during Prehistory: Interim report 2020") URL: https://hal.archives-ouvertes.fr/hal-03161478

Chalmin, E., Schmitt, B., Chanteraud, C., Chassin de Kergommeaux, A., Soufi, F. \& Salomon, H. 2021b, How to distinguish red coloring matter used in prehistoric time? The contribution of visible near-infrared diffuse reflectance spectroscopy. Color Research \& Application, 46(3): 1- 21. doi:10.1002/col.22647 
Chanteraud, C. 2020, Provenance des matières colorantes dans le contexte des grottes ornées des Gorges de l'Ardèche. Stratégie d'approvisionnement et liens culturels au Paléolithique supérieur: le cas de la grotte aux Points (Aiguèze, Gard, France), $\mathrm{PhD}$ thesis, NNT: 2020CHAMA017, HAL id: tel-03184877, at the Department of Materials chemistry, Savoie Mont Blanc University, Le Bourget-du-Lac, 282 p. (in French) ("Provenance of colouring materials in the context of the decorated caves of the Gorges de l'Ardèche. Supply strategy and cultural links in the Upper Palaeolithic: The case of the Points cave (Aiguèze, Gard, France)”) URL: https://tel.archives-ouvertes.fr/tel03184877

Chanteraud, C., Chalmin, É., Lebon, M., Salomon, H., Jacq, K., Noûs, C., Delannoy, J.-J. \& Monney, J. 2021, Contribution and limits of portable X-ray fluorescence for studying Palaeolithic rock art: A case study at the Points cave (Aiguèze, Gard, France). Journal of Archaeological Science: Reports, 37: 102898: 14 p. doi:10.1016/j.jasrep.2021.102898

Chassin de Kergommeaux, A., Salomon, H., Monney, J., Chanteraud, C., Jean-Victor, P., Goemaere, É., Leduc T. \& Chalmin, E. 2021, Référencement géologique des ressources en matières colorantes entre l'Ardèche et le Gardon. Un outil pour appréhender les paysages vécus au cours du Paléolithique supérieur. Ardèche archéologie, 38: 14-23. (in French) ("Geological referencing of dye resources between the Ardèche and Gardon rivers. A tool for understanding the landscapes experienced during the Upper Palaeolithic”)

Choquette, P.W. \& Pray, L.C. 1970, Geologic nomenclature and classification of porosity in sedimentary carbonates. AAPG bulletin, 54(2): 207-250. doi:10.1306/5D25C98B16C1-11D7-8645000102C1865D

Cojan, I. \& Renard, M. 1999, Sédimentologie. 2e Cycle. Capes. Agrégation, Dunod, Paris, 444 p. (in French) (“Sedimentology. Second cycle. Capes. Aggregation”)

Coquinot, Y. \& Salomon, H. (2013), Les “matériaux” ferrugineux géologiques et transformés (presentation). Presented at the Intedisciplinary thematic school of the CNRS ArFeMa, Oléron, France, 9-14 juin 2013. (in French) (“Geological and transformed ferrouginous materials”)

Cornell, R.M. \& Schwertmann, U. 2003, The iron oxides: Structure, properties, reactions, occurrences and uses. John Wiley \& Sons, New York, 573 p.

Couraud, C. 1983, Pour une étude méthodologique des colorants préhistoriques. Bulletin de la Société préhistorique française, 80(4): 104-110; Accessed 2021-11-13. (in French)

("For a methodological study of prehistoric colourants")

URL: https://www.persee.fr/doc/bspf_0249-7638_1983_num_80_4_5429

Couraud, C. 1991, Les pigments des grottes d'Arcy-sur-Cure (Yonne). Gallia préhistoire, 33(1): 17-52. (in French) ("The pigments of the caves at Arcy-sur-Cure (Yonne)") URL: https://www.persee.fr/doc/galip_00164127_1991_num_33_1_2284?pageId=T1_47

Couraud, C. \& Laming-Emperaire, A. 1979, Les colorants. In: Lascaux inconnu (Allain, J., Ed.): supplément à Gallia Préhistoire, CNRS, Paris, 12, p. 159-171. (in French) (“The colourants") 
Courty, G. 1902, Examen chimique de deux matières colorantes trouvées dans des stations préhistoriques du Périgord. Bulletins de la Société d'anthropologie de Paris, 3(1): 840. (in French) ("Chemical examination of two colouring materials found in prehistoric sites in the Périgord”) URL: https://www.persee.fr/doc/bmsap_03018644_1902_num_3_1_6102

Cuenca-Solana, D., Gutiérrez-Zugasti, I., Ruiz-Redondo, A., Gonzalez-Morales, M. R., Setién, J., Ruiz-Martínez, E., Palacio-Pérez, E., de las Heras-Martin, C., PradaFreixedo, A. \& Lasheras-Corruchaga, J. A. 2016, Painting Altamira Cave? Shell tools for ochre-processing in the Upper Palaeolithic in northern Iberia. Journal of Archaeological Science, 74: 135-151. doi:10.1016/j.jas.2016.07.018

Damour, A. 1865, Sur la composition des haches en pierre trouvées dans les monuments celtiques et chez les sauvages. Comptes rendus de l'Académie des sciences, 61: 1-13. (in French) ("On the composition of stone axes found in Celtic monuments and among savages”)

David, B., Delannoy, J.-J., Mialanes, J., Clarkson, C., Petchey, F., Geneste, J.-M., Manne, T., Bird, M.I., Barker, B., Richards, T., Chalmin, E. \& Castets, G. 2019, Dating painting events through by-products of ochre processing: Borologa 1 Rockshelter, Kimberley, Australia. Australian Archaeology, 85(1): 57-94. doi:10.1080/03122417.2019.1603263

Dayet, L. 2012, Matériaux, transformations et fonctions de l'ocre au Middle Stone Age: le cas de Diepkloof Rock Shelter dans le contexte de l'Afrique australe, NNT:

2012BOR30048, HAL id: tel-00814875v2, at the department of Archaeometry, Michel de Montaigne University, Bordeaux, 407 p. (in French) ("Raw material, processing and function of ochre remains during the MSA: The case study of Diepkloof Rock Shelter in southern Africa”) URL: https://tel.archives-ouvertes.fr/tel-00814875/

Dayet L. 2021, Invasive and Non-Invasive Analyses of Ochre and Iron-Based Pigment Raw Materials: A Methodological Perspective. Minerals, 11(2): 210. doi:10.3390/min11020210

Dayet, L., Le Bourdonnec, F.-X., Daniel, F., Porraz, G. \& Texier, P.-J. 2015, Ochre Provenance and Procurement Strategies During The Middle Stone Age at Diepkloof Rock Shelter, South Africa. Archaeometry, 58(5): 807-829. doi:10.1111/arcm.12202

Dayet, L., Wurz, S. \& Daniel, F. 2017, Ochre Resources, Behavioural Complexity and Regional Patterns in the Howiesons Poort: New Insights From Klasies River Main Site, South Africa. Journal of African Archaeology, 15(1): 20-41. doi:10.1163/2191578412340002

Delvigne, V., Fernandes, P., Tuffery, C., Raynal, J. P. \& Klaric, L. 2020, Taphonomic methods and a database to establish the origin of sedimentary silicified rocks from the Middle-recent Gravettian open-air site of La Picardie (Indre-et-Loire, France). Journal of Archaeological Science: Reports, 32: 102369: 18 p. doi:10.1016/j.jasrep.2020.102369

Delvigne, V., Touzé, O. \& Noiret, P., in press, Siliceous raw material exploitation at Station de l'Hermitage: A palaeogeographic perspective on North-Western Europe during the Early Gravettian. In: Proceedings of the symposium North-Western Europe during the Gravettian. Contributions of recent research to the understanding of the societies and their environments, University of Liège, 12-13 april 2018 (Touzé, O., Goutas, N., Salomon, H. \& Noiret, P., Eds.), ERAUL, Vol. 150 \& Anthropologica et Praehistorica, Vol. 130, Societe Royale Belge d'Anthropologie et de Prehistoire, Bruxelles: 109-128. 
Demars, P.-Y. 1992, Les colorants dans le Moustérien du Périgord. L’apport des fouilles de F. Bordes. Bulletin de la Société préhistorique ariégeoise, 47: 185-195. (in French) ("Colourants in the Mousterian of the Périgord. The contribution of F. Bordes' excavations”)

Denayer, J. 2016, Iron ores of Southern Belgium: Much more than hematite. In: About haematite. Procurement and transformation during Recent Prehistory. Proceedings of the international Round Table, 7-8/02/2013, Namur (Jambes) (Billard, C., Bosquet, D., Dreesen, R., Goemaere, É., Hamon, C., Jadin, I., Salomon, H. \& Savary, X., Eds.), Anthropologica et Praehistorica Vol. 126, Societe Royale Belge d'Anthropologie et de Prehistoire, Bruxelles, p. 39-49.

Denayer, J., Pacyna, D. \& Boulvain F. 2011, Le minerai de fer en Wallonie: cartographie, historique et géologie. Ed. de la Région Wallonne, Jambes, 250 p. (in French) ("Iron ore in Wallonia: Map, history and geology”)

Dill, H. 1985, Terrestrial ferromanganese ore concentrations from mid-european basement blocks and their implication concerning the environment of formation during the late cenozoic (northern Bavaria, F.R.G.). Sedimentary Geology, 45: 77-96. doi:10.1016/0037-0738(85)90024-7

Dott, R.H. 1964, Wacke, graywacke and matrix; what approach to immature sandstone classification? Journal of Sedimentary Research, 34(3): 625-632. doi:10.1306/74D71109-2B21-11D7-8648000102C1865D

Dreesen, R., Savary, X. \& Goemaere, E. 2016, Definition, classification and microfacies characteristics of oolitic ironstones used in the manufacturing of red ochre - a comparative petrographical analysis of Palaeozoic samples from France, Belgium and Germany. In: About haematite. Procurement and transformation during Recent Prehistory. Proceedings of the international Round Table, 7-8/02/2013, Namur (Jambes) (Billard, C., Bosquet, D., Dreesen, R., Goemaere, É., Hamon, C., Jadin, I., Salomon, H. \& X. Savary, X., Eds.), Anthropologica et Praehistorica Vol. 125, Societe Royale Belge d'Anthropologie et de Prehistoire, Bruxelles, p. 203-223.

Dubinina, G.A., Sorokina, A.Y., Gapeeva, M.V. \& Dolotov, A.V. 2012, Communities of neutrophilic iron-oxidizing microorganisms of ferruginous springs of various types and their involvement in fractionation of stable iron isotopes. Microbiology, 81(1): 90-97. doi:10.1134/S0026261712010055

Dunham, R.J. 1962, Classification of Carbonate Rocks According to Depositional Texture 1. In: Classification of Carbonate Rocks - A Symposium Vol. 1, American Association of Petroleum Geologists, p. 108-121.

Dupuis, C. \& Beaudoin, G. 2011, Discriminant diagrams for iron oxide trace element fingerprinting of mineral deposit types. Mineralium Deposita, 46: 319-35. doi:10.1007/s00126-011-0334-y

Eiselt, B.S., Popelka-Filcoff, R.S., Darling, J.A. \& Glascock, M.D. 2011, Hematite sources and archaeological ochres from Hohokam and O’odham sites in central Arizona: An experiment in type identification and characterization. Journal of Archaeological Science, 38(11): 3019-3028. doi:10.1016/j.jas.2011.06.030 
d’Errico, F., García-Moreno, R. \& Rifkin, R. F. 2012, Technological, elemental and colorimetric analysis of an engraved ochre fragment from the Middle Stone Age levels of Klasies River Cave 1, South Africa. Journal of Archaeological Science, 39(4): 942952. doi:10.1016/j.jas.2011.10.032

d'Errico, F., Salomon, H., Vignaud, C. \& Stringer, C. 2010, Pigments from the middle palaeolithic levels of Es-Skhul (Mount Carmel, Israel). Journal of Archaeological Science, 37(12): 3099-3110. doi:10.1016/j.jas.2010.07.011

Evans, A. M., 1993, Ore geology and industrial minerals an introduction. 3rd edition, Blackwell Scientific Publications, Singapore, 400 p.

Fernandes, P. 2012, Itinéraires et transformations du silex: une pétroarchéologie refondée, application au Paléolithique moyen, PhD thesis, NNT: 2012BOR14533, at the department of Prehistory, Bordeaux-1 University, Bordeaux, 623 p. (in French) ("Routes and transformations of flint: A refounded petroarchaeology, application to the Middle Palaeolithic”)

Fernandes, P. 2015, Réseau de lithothèques en Rhône-Alpes. ADLFI. Archéologie de la France-Informations. Une revue Gallia, 1288: 1-4.

URL: http://journals.openedition.org/adlfi/15033

Fernandes, P., Delvigne, V., Vaissié, E., Piboule, M., Tuffery, C., Beeching, A., BressyLeandri, C., Binder, D., Le Bourdonnec, F.-X., Queffelec, A., Dubernet, S., Stephan, Schmidt, P., Platel, J.-P., Thiry, M., Caux, S.n., Morala, A., Turq, A., Querré, G., Bintz, P., Lea, V., Langlais, M., Gibaud, A., Gély, B., Harold, L., Perrin, T., Liagre, J., Dessaint, P., Gaillot, S., Tomasso, A., Beauvais, P.-A., Liabeuf, R., Morin, A., Morin, E., Tallet, P., robbe, j., Lafarge, A., Cousseran-Néré, S., Chesnaux, L.n., Moreau, L., Guillermin, P., Raynal, J.P., Deparnay, X., Kherdouche, A. \& Guibert, P. 2019, Réseau de lithothèques en Auvergne - Rhône-Alpes. Paléotime. Service régional de l'archéologie Auvergne - Rhône-Alpes p. 201; Accessed: 2019-01-01. (in French) (“Network of lithotheques in Auvergne - Rhône-Alpes”) URL: https:/hal.archives-ouvertes.fr/hal02549674

Fernandes, P. \& Raynal, J.-P. 2006, Pétroarchéologie du silex: un retour aux sources. Comptes rendus Palevol, 5: 829-837. (in French) ("Petroarchaeology of flint: Back to sources”) doi:10.1016/j.crpv.2006.04.002

Flick, H. \& Nesbor, H. D. 1988, Der Vulkanismus in der Lahnmulde. Jahresberichte und Mitteilungen des Oberrheinischen Geologischen Vereins, 70: 411-475. (in German) ("Volcanism in the Lahn Basin”) doi:10.1127/jmogv/70/1988/411

Flick, H., Nesbor, H. D. \& Behnisch, R. 1990, Iron ore of the Lahn-Dill type formed by diagenetic seeping of pyroclastic sequences-a case study on the Schalstein section at Gänsberg (Weilburg). Geologische Rundschau, 79(2): 401-415. doi:10.1007/BF01830635

Folk, R.L. 1959, Practical petrographic classification of limestones. Bulletin of the American Association of Petroleum Geologist, 43(1): 1-38. doi:10.1306/0BDA5C36-16BD-11D78645000102C1865D 
Galbrun, B., Baudin, F., Bassoullet, J. P., Depeche, F., Emmanuel, L., Lachkar, G., Renard, M., Riveline, J., Gabilly, J., Hantzpergue, P., Manivit, H. \& Ruget, C. 1994, Stratigraphie intégrée du Toarcien stratotypique (coupes de Thouars et Airvault, DeuxSèvres, France). Geobios, 27: 575-595. (in French) ("Integrated stratigraphy of the Toarcian stratotypic (Thouars and Airvault sections, Deux-Sèvres, France)”) doi:10.1016/S0016-6995(94)80222-X

Garilli, V., Vita, G., La Parola, V., Vraca, M.P., Giarrusso, R., Rosina, P., Bonfiglio, L. \& Sineo, L. 2020, First evidence of Pleistocene ochre production from bacteriogenic iron oxides. A case study of the Upper Palaeolithic site at the San Teodoro Cave (Sicily, Italy). Journal of Archaeological Science, 123: 105221. doi:10.1016/j.jas.2020.105221

Glavenchuk, A. V. 2012, The Use of Pigment Ochre at the Late Palaeolithic Site of Anetovka II. Stratum Plus Journal, 1: 293-300.

Green, R.L. \& Watling, R.J. 2007, Trace Element Fingerprinting of Australian Ocher Using Laser Ablation Inductively Coupled Plasma-Mass Spectrometry (LA-ICP-MS) for the Provenance Establishment and Authentication of Indigenous Art. Journal of Forensic Science, 52(4): 851-859.

Godelier, M. 1984, L’idéel et la matériel. Pensée, économies, sociétés. Fayard, Paris: 348 p. (in French) ("The Mental and the material. Through economy and society")

Godelier, M.1986, The Mental and the Material. Through economy and society. Verso, London: 350 p.

Godelier, M. 2009, Au fondement des sociétés humaines. Albin Michel, Paris, 295 p. (in French) (“At the foundation of human societies")

Goemaere, E., Katsch A., Eschghi, I. \& Dreesen, R. 2016a, Geological record and depositional setting of Palaeozoic oolitic ironstones in Western Europa. In: About haematite. Procurement and transformation during Recent Prehistory. Proceedings of the international Round Table, 7-8/02/2013, Namur (Jambes) (Billard, C., Bosquet, D., Dreesen, R., Goemaere, É., Hamon, C., Jadin, I., Salomon, H. \& Savary, X., Eds.), Anthropologica et Praehistorica Vol. 125, Societe Royale Belge d'Anthropologie et de Prehistoire, Bruxelles, p. 23-43.

Goemaere, E., Salomon, H., Billard, C., Querré, G., Mathis, F., Golitko, M., DubrulleBrunaud, C., Savary, X. \& Dreesen, R. 2016b, Les hématites oolithiques du Néolithique ancien et du Mésolithique de Basse-Normandie (France): caractérisation physicochimique et recherche des provenances. In: About haematite. Procurement and transformation during Recent Prehistory. Proceedings of the international Round Table, 7-8/02/2013, Namur (Jambes) (Billard, C., Bosquet, D., Dreesen, R., Goemaere, É., Hamon, C., Jadin, I., Salomon, H. \& Savary, X., Eds.), Anthropologica et Praehistorica Vol. 125, Societe Royale Belge d'Anthropologie et de Prehistoire, Bruxelles, p. 89-119. (in French) ("Early Neolithic and Mesolithic oolitic hematites from Lower Normandy (France): Physico-chemical characterisation and provenance research") 
Goemaere, E., Salomon, H., Querré, G., Mathis, F., Dreesen, R., Hamon, C., Constantin, C., Bosquet, D., Wijnen, J. \& Jadin, I. 2016c, Caractérisation physico-chimique et recherche des provenances des hématites oolithiques des sites du Néolithique ancien de Hesbaye (Province de Liège, Belgique) et des sites néolithiques des sources de la Dendre (Province du Hainaut, Belgique). In: About haematite. Procurement and transformation during Recent Prehistory. Proceedings of the international Round Table, 7-8/02/2013, Namur (Jambes) (Billard, C., Bosquet, D., Dreesen, R., Goemaere, É., Hamon, C., Jadin, I., Salomon, H. \& Savary, X., Eds.), Anthropologica et Praehistorica Vol. 125, Societe Royale Belge d'Anthropologie et de Prehistoire, Bruxelles, Bruxelles, p. 153-191. (in French) ("Physico-chemical characterisation and research into the origins of oolitic hematites from the Early Neolithic sites of Hesbaye (Province of Liège, Belgium) and the Neolithic sites of the Dendre springs (Province of Hainaut, Belgium)”)

Gould, R.A. \& Saggers, S. 1985, Lithic procurement in Central Australia: A closer look at Binford's idea of embeddedness in archaeology. American Antiquity, 5(1): 117-136. doi:10.2307/280637

Gourdon-Platel, N. \& Lambert, P. 1986, Microstructures et répartition de trois éléments majeurs (Fe, Al, Si) au sein des pisolites de fer nord-aquitains. Travaux du Laboratoire de Géographie Physique Appliquée, 10(1): 5-22. (in French) ("Microstructures and distribution of three major elements (Fe, $\mathrm{Al}, \mathrm{Si})$ within the North-Aquitaine iron pisolites”)

Gourdon-Platel, N., Platel, J.-P. \& Astruc, J.-G. 2000, La Formation de Rouffignac, témoin d'une paléoaltéritecuirassée intra-éocèneen Périgord-Quercy. Géologie de la France, 1: 65-67. (in French) (“The Rouffignac Formation, evidence of an intra-Eocene palaeoalterite-cirasse in Périgord-Quercy”)

Guendon, J.-L. \& Parron, C. 1985, Les phénomènes karstiques dans les processus de la bauxitisation sur substrat carbonaté. Exemples des gisements du sud-est de la France. Annales de la Société Géologique de Belgique, 108: 85-92. (in French) ("Karstic phenomena in the processes of bauxitisation on carbonate substratum. Examples of deposits in south-eastern France”)

Haldar, S. K. 2018, Chapter 5: Exploration Geochemistry, In: Mineral exploration (Second Edition): Principles and applications (S.K. Haldar, Ed.), Elsevier, p. 85-101.

Henshilwood, C. S., d’Errico, F., Van Niekerk, K. L., Coquinot, Y., Jacobs, Z., Lauritzen, S. E., Menu, M. \& García-Moreno, R. 2011, A 100,000-year-old ochre-processing workshop at Blombos Cave, South Africa. Science, 334(6053): 219-222. doi:10.1126/science.1211535

Henshilwood, C.S., d'Errico, F. \& Watts, I. 2009, Engraved ochres from the middle stone age levels at Blombos Cave, South Africa. Journal of human evolution, 57(1): 27-47. doi:10.1016/j.jhevol.2009.01.005

Hodgskiss, T. \& Wadley, L. 2017, How people used ochre at Rose Cottage Cave, South Africa: Sixty thousand years of evidence from the Middle Stone Age. PloS one, 12(4), e0176317. doi:10.1371/journal.pone.0176317

Hovers, E., Ilani, S., Bar-Yosef, O. \& Vandermeersch, B. 2003, An early case of color symbolism: Ochre use by modern humans in Qafzeh Cave. Current anthropology, 44(4): 491-522. doi:10.1086/375869 
Iriarte, E., Foyo, A., Sánchez, M. A., Tomillo, C., \& Setién, J. 2009, The origin and geochemical characterization of red ochres from the Tito Bustillo and Monte Castillo caves (northern Spain). Archaeometry, 51(2): 231-251. doi:10.1111/j.14754754.2008.00397.x

James, R. E. \& Ferris, F. G. 2004, Evidence for microbial-mediated iron oxidation at a neutrophilic groundwater spring. Chemical Geology, 212(3-4): 301-311. doi:10.1016/j.chemgeo.2004.08.020

Jébrak, M. \& Marcoux, É. 2008, Géologie des ressources minérales. Ministère des ressources naturelles et de la faune, Québec, 668 p. (in French) (“Geology of mineral resources”)

Jones, P. 1984, Red Ochre Expeditions: An Ethnographic and Historical Analysis of Aboriginal Trade in the Lake Eyre Basin. Part I. Journal of the Anthropological Society of South Australia, 22(7): 3-10.

Kenyon, S.M. 1980, Kyuquot way A study of a West Coast (Nootkan) community. University of Ottawa Press, 210 p. doi:10.2307/j.ctv1744p

Kholodov, V. N., Nedumov, R. I. \& Golubovskaya, E. V. 2012, Facies Types of Sedimentary Iron Ore Deposits and Their Geochemical Features: Communication 1. Facies Group sof Sedimentary Ores, Their Lithology, and Genesis. Lithology and Mineral Resources, 47(6): 447-472. doi:10.1134/S0024490212060053

de Lapparent, J. 1930, Les bauxites de la France méridionale. Imprimerie nationale, Paris, 211 p. (in French) ("Bauxites of southern France”)

Lartet, E. \& Christy, H. 1875, Reliquiae Aquitanicae, being contributions to the archaeology and palaeontology of Perigord and the adjoining provinces of Southern France, William and Norgate, London, 506 p.

Lebon, M., Beck, L., Grégoire, S., Chiotti, L., Nespoulet, R., Menu, M. \& Paillet, P. 2014, Prehistoric pigment characterisation of the Abri Pataud rock-shelter (Dordogne, France). Open Journal of Archaeometry, 2(1). doi:10.4081/arc.2014.5456

Lebon, M., Gallet, X., Bondetti, M., Pont, S., Mauran, G., Walter, P., Bellot-Gurlet, L., Puaud, S., Zazzo, A., Forestier, H., Auetrakulvit, P. \& Zeitoun, V. 2019, Characterization of Painting Pigments and Ochres Associated with the Hoabinhian Archaeological Context at the Rock-Shelter Site of Doi Pha Kan (Thailand). Journal of Archaeological Science: Reports, 26: 101855: 16 p. doi:10.1016/j.jasrep.2019.05.020

Lenehan, C. E., Tobe, S. S., Smith, R. J. \& Popelka-Filcoff, R. S. 2017, Microbial composition analyses by 16S rRNA sequencing: A proof of concept approach to provenance determination of archaeological ochre. PloS one, 12(10): e0185252. doi:10.1371/journal.pone.0185252

Levett, A., Vasconcelos, P. M., Gagen, E. J., Rintoul, L., Spier, C., Guagliardo, P. \& Southam, G. 2020, Microbial weathering signatures in lateritic ferruginous duricrusts. Earth and Planetary Science Letters, 538: 116209. doi:10.1016/j.epsl.2020.116209

Lozet, J. \& Mathieu, C. 2002, Dictionnaire des sciences du sol. Editions TEC \& DOC, Paris, 574 p. (in French) ("Dictionnary of soil science")

Lundegard, P.D. \& Samuels, N.D. 1980, Field classification of fine-grained sedimentary rocks. Journal of Sedimentary Research, 50(3): 781-786. doi:10.1306/212F7AE5-2B2411D7-8648000102C1865D 
MacDonald, B. L., Fox, W., Dubreuil, L., Beddard, J. \& Pidruczny, A. 2018, Iron oxide geochemistry in the Great Lakes Region (North America): Implications for ochre provenance studies. Journal of Archaeological Science: Reports, 19: 476-490. doi:10.1016/j.jasrep.2018.02.040

MacDonald, B. L., Stalla, D., He, X., Rahemtulla, F., Emerson, D., Dube, P. A., Maschmann, M.R., Klesner, C.E. \& White, T. A. 2019, Hunter-gatherers harvested and heated microbial biogenic iron oxides to produce rock art pigment. Scientific Reports, 9(1): 113. doi:10.1038/s41598-019-53564-w

Mackay, A. \& Welz, A. 2008, Engraved ochre from a middle stone age context at Klein Kliphuis in the Western Cape of South Africa. Journal of Archaeological Science, 35(6): 1521-1532. doi:10.1016/j.jas.2007.10.015

Mamet, B. \& Boulvain, F. 1990, Microorganismes ferro-oxydants de Griottes carbonifères espagnoles. Bulletin de la Société Belge de Géologie, 99(2): 229-239. (in French) ("Ferrooxidising microorganisms of Spanish carbonaceous red and brown speckled marble”)

Mamet, B. \& Préat, A. 2003, Sur l'origine bactérienne et fongique de la pigmentation de l'Ammonitico Rosso (Jurassique, région de Vérone, Italie du nord). Revue de micropaléontologie, 46(1): 35-46. (in French) ("On the bacterial and fungal origin of the Ammonitico Rosso pigmentation (Jurassic, Verona region, northern Italy)”) doi:10.1016/S0035-1598(03)00006-0

Mathis, F., Bodu, P., Dubreuil, O. \& Salomon, H. 2014, PIXE identification of the provenance of ferruginous rocks used by Neanderthals. Nuclear Instruments and Methods in Physics Research Section B: Beam Interactions with Materials and Atoms, 331: 275-279. doi:10.1016/j.nimb.2013.11.028

Mauran, G., Caron, B., Détroit, F., Nankela, A., Bahain, J.-J., Pleurdeau, D. \& Lebon, M. 2021, Data pretreatment and multivariate analyses for ochre sourcing: Application to Leopard Cave (Erongo, Namibia). Journal of Archaeological Science: Reports, 35: 102757: 16 p. doi:10.1016/j.jasrep.2020.102757

McQueen, K. G. 2005, Towards understanding the ferruginous component of the regolith. In: Abstracts of the Minerals Exploration Seminar, CRC LEME-GSWA, Feb 2005. Kalgoorlie, Western Australia, p. 18-23.

Moissan, H., 1902, Sur les matières colorantes des figures de la grotte de Font-de-Gaume. Comptes Rendus de l'Académie des sciences, 134: 1539-1540. (in French) (“On the colouring matter of the figures in the Font-de-Gaume cave”)

Moissan, H. 1903, Sur une matière colorante des figures de la Grotte de la Mouthe. Comptes rendus de l'Académie des sciences, 135: 144-145. (in French) ("On a colouring matter of the figures in la Mouthe cave")

Monteiro, H.S., Vasconcelos, P.M.P., Farley, K.A., Lopes, C.A.M. 2018, Age and evolution of diachronous erosion surfaces in the Amazon: Combining (U-Th)/He and cosmogenic 3 He records. Geochima et Cosmochima Acta, 229: 162-183. doi:10.1016/j.gca.2018.02.045

de Mortillet, G. \& de Mortillet, A. 1910, La Préhistoire. Origine et antiquité de l'Homme. Bibliothèque des Sciences contemporaines, Schleicher Frères, Paris, 709 p. (in French) ("Prehistory. Origin and antiquity of Man") 
Mount, J. 1985, Mixed siliciclastic and carbonate sediments: A proposed first-order textural and compositional classification. Sedimentology, 32: 435-442. doi:10.1111/j.13653091.1985.tb00522.x

Mustoe, G. E. 1981, Bacterial oxidation of manganese and iron in a modern cold spring. Geological Society of America Bulletin, 92(3): 147-153. doi:10.1130/00167606(1981)92<147:BOOMAI>2.0.CO;2

Nesbor, H. D. 2007, Paläozoischer Vulkanismus im Lahn-Dill-Gebiet-südöstliches Rheinisches Schiefergebirge (Exkursion E am 12. April 2007). Jahresberichte und Mitteilungen des Oberrheinischen Geologischen Vereins, 89: 193-216. (in German) ("Palaeozoic volcanism in the Lahn-Dill area-southeastern Rhenish Schiefergebirge (excursion E on 12 April 2007)”) doi:10.1127/jmogv/89/2007/193

Nicod, J. 1996, Karst et mines en France et en Europe: gîtes, grottes-mines et géotechnique. Karstologia, 27(1): 1-20.(in French) ("Karst and mines in France and Europe: Deposits, cave-mines and geotechnics”)

Nicolas, J. 1968, Nouvelles données sur la genèse des bauxites à mur karstiques du Sud-Est de la France. Leur origine latéritique, leur transport et leur dépôt en milieu aqueux sous forme de bauxite déjà constituée. Mineralium Deposita, 3: 18-33. (in French) ("New data on the genesis of karst-walled bauxites in south-eastern France. Their lateritic origin, their transport and their deposition in an aqueous medium in the form of already constituted bauxite”)

Onoratini, G. 1985, Diversité minérale et origine des matériaux colorants utilisés dès le Paléolithique supérieur en Provence. Bulletin du Musée d'Histoire Naturelle de Marseille, 45, 7-114. (in French) ("Mineral diversity and origin of colouring materials used since the Upper Palaeolithic in Provence")

Pavia, G., Corbin, L., Defaveri, A., Maerten, L. \& Olivero, D. 2015, La formation de l'oolithe ferrugineuse de Bayeux du Bajocien (Jurassique moyen) au lieut-dit "Les fours à chaux" entre Croisilles et les Moutiers-en-Cinglais (Calvados, NW France). Geologie de la France, 2: 5-17. (in French) ("The formation of the Bajocian (Middle Jurassic) Bayeux iron oolite at "Les fours à chaux" between Croisilles and Moutiers-en-Cinglais (Calvados, NW France)")

Petersen, U. 1971, Laterite and bauxite formation. Economic Geology, 66(7): 1070-1071. doi:10.2113/gsecongeo.68.3.353

Pettijohn, F. J. 1975, Sedimentary rocks. New York: Harper \& Row, 628 p.

Pettijohn, F.J., Potter, P.E. \& Siever, R. 1987, Texture. In: Sand and Sandstone (Pettijohn, F.J., Potter, P.E. \& Siever, R., Eds.). Springer, New York, NY, p. 69-95.

Popelka-Filcoff, R.S. \& Charrison, E. 2012, Chemical archaeology: On the trail of aboriginal ochre. Chemistry in Australia, (june 2012): 20-23. doi:10.3316/ielapa.425771635454880

Popelka-Filcoff, R. S., Miksa, E. J., Robertson, J. D., Glascock, M. D. \& Wallace, H. 2008, Elemental analysis and characterization of ochre sources from Southern Arizona. Journal of archaeological science, 35(3), 752-762. doi:10.1016/j.jas.2007.05.018

Popelka-Filcoff, R. S., Robertson, J. D., Glascock, M. D. \& Descantes, C. 2007, Trace element characterization of ochre from geological sources. Journal of Radioanalytical and Nuclear Chemistry, 272(1), 17-27. doi:10.1007/s10967-006-6836-X 
Pradeau, J.-V., Salomon, H., Bon, F., Mensan, R., Lejay, M. \& Regert, M. 2014, Les matières colorantes sur le site aurignacien de plein air de Régismont-le-Haut (poilhes, hérault). Bulletin de la Société préhistorique française, 111(4): 631-658. (in French) ("Colouring materials on the Aurignacian open-air site of Régismont-le-Haut (Poilhes, Hérault)”)

Pradeau, J.-V. 2015, Les matières colorantes au sein des systèmes techniques et symboliques au Néolithique (VIe et Ve millénaires BCE) dans l'arc liguro-provençal, $\mathrm{PhD}$ thesis, NNT: 2015NICE2019, tel-01218726, at the department of Prehistory, Nice Sophia Antipolis University, 427 p. (in French) ("Colouring materials within technical and symbolic systems in the Neolithic (6th and 5th millennia BCE) in the Liguro-Provençal arc)")

Pradeau, J.-V., Binder, D., Verati, C., Lardeaux, J.-M. Dubernet, S., Lefrais, Y. \& Regert, M. 2016, Procurement strategies of Neolithic colouring materials: Territoriality and networks from 6th to 5th millennia in North-Western Mediterranean. Journal of Archaeological Science, 71:10-23. doi:10.1016/j.jas.2016.05.007

Préat, A., Mamet, B., Bernard, A. \& Gillan, D. 1999, Bacterial mediation, red matrices diagenesis, Devonian, Montagne Noire (southern France). Sedimentary Geology, 126: 223-242. doi:10.1016/S0037-0738(99)00042-1

Préat, A., Mamet, B., De Ridder, C., Boulvain, F. \& Gillan, D. 2000, Iron bacterial and fungal mats, Bajocian stratotype (Mid-Jurassic, northern Normandy, France). Sedimentary Geology, 137(3-4): 107-126. doi:10.1016/S0037-0738(00)00101-9

Prothero, D.R. \& Schwab, F. 2014, Sedimentary geology. Introduction to Sedimentary rocks and Stratigraphy, Freeman \& Compagny, New York, 604 p.

Quinif, Y. 1993, Les phénomènes karstiques en Calestienne. De la Meuse à l'Ardenne, 16: 55-75. (in French) ("Karst phenomena in Calestienne”)

Regert, M. 1995, Les matières colorantes. Combe Saunière 1. Field report 1995. (Unpublished report for the Service Régional de l’Archéologie, Bordeaux), 26 p. (in French) (“Colouring matter. Combe Saunière 1")

Rifkin, R.F. 2012a, Processing ochre in the Middle Stone Age: Testing the inference of prehistoric behaviours from actualistically derived experimental data. Journal of Anthropological Archaeology, 31(2): 174-195. doi:10.1016/j.jaa.2011.11.004

Rifkin, R.F. 2012b, The symbolic and functional exploitation of ochre during the south african Middle Stone Age. PhD thesis, at the Faculty of Science, University of the Witwatersrand, Johannesburg.

Rivière, E. 1887, Paleoethnologie. De l'antiquité de l'Homme dans les Alpes maritimes. J.-B. Baillère \& Fils Editeurs, Paris, 482 p.

Robb, L. J. 2005, Introduction to ore-forming processes. Blackwell Pub, Malden, MA, 373 p.

Rosenthal, P. 1991, Les minerais de fer de France-Comté. Bulletin de la Société d'Histoire naturelle du Doubs, 85: 25-62. (in French) (“The iron ores of Franche-Comté”)

Rossi, M. \& Gasquet, D. 2014, Panorama géologique des exploitations minières dans les alpes françaises. Collection EDYTEM. Cahiers de géographie, 17(1): 23-40. (in French) (“Geological overview of mining in the French Alps”)

Rosso, D. E., d'Errico, F. \& Zilhão, J. 2014, Stratigraphic and spatial distribution of ochre and ochre processing tools at Porc-Epic Cave, Dire Dawa, Ethiopia. Quaternary International, 343: 85-99. doi:10.1016/j.quaint.2013.10.019 
Routhier, P. 1963, Les gisements métallifères. Ed. Masson, Paris, 1282 p. (in French) ("Metal deposits”)

Sajó, I.E., Kovács, J., Fitzsimmons, K. E., Jáger, V., Lengyel, G., Viola, B., Talamo, S. \& Hublin, J. J. 2015, Core-Shell processing of natural pigment: Upper Palaeolithic red ochre from Lovas, Hungary. PloS one, 10(7), e0131762. doi:10.1371/journal.pone.0131762

Salomon, H. 2003, Gestion des matières colorantes durant le Paléolithique: expérimentations et étude des oxydes de manganèse de Combe Saunière (Dordogne), Master 1 thesis, at the Department of Prehistory, Paris 1 Sorbonne University, France, 80 p. (in French) ("Colouring materials exploitation during the Palaeolithic: Experimentations and study of the manganese oxydes at Combe Saunière (Dordogne)”)

Salomon, H. 2004, Caractérisation et transformations techniques des matières colorantes dans le Solutréen de l'Ouest de la France, Master 2 thesis, at the Department of Prehistory, Paris 1 Sorbonne University, 84 p. (in French) ("Characterisation and technical transformations of colouring materials in the Solutrean context of Western France”)

Salomon, H. 2009, Les matières colorantes au début du Paléolithique supérieur: Sources, transformations et fonctions, PhD thesis, NNT: 2012BOR13971, at the academic department of Prehistory, Bordeaux 1 University, 413 p; Accessed 2021-11-13. (in French) ("Colouring materials at the onset of the Upper Palaeolithic: Origins, transformations and fonctions”) URL: https://hal.archives-ouvertes.fr/tel-02430482

Salomon, H. 2019, Les matières colorantes. Partie III - Les activités et leurs témoins. In: Le Châtelperronien de la grotte du Renne (Arcy-sur-Cure, Yonne, France). Les fouilles d'André Leroi-Gourhan (1949-1963) (Julien, M., David, F., Girard, M., Roblin-Jouve, A., Eds.), Paléo, numéro spécial, p. 197-242. (in French) ("The colouring materials. Part 3 - Activities and their evidence”)

Salomon, H., Chalmin, E., Chassin de Kergommeaux, A., Chanteraud, C., Abbassy, S., Camizuli, E., Delvigne, V., Develle-Vincent, A.-L., Dubreuil, O., Fernandes, P., Gasquet, D., Genuite, K.,Goemaere, E., Lebon , M., Lemasson, Q., Mauran, G., Mensan, R., Pacheco, C., Pichon, L., Pignol, C., Rossi, M., Schmitt, B., Soufi, F. \& Tuffery, C. 2019, Construction d'une Pigmentothèque: un outil pour comprendre l'approvisionnement en matériaux colorants durant la Préhistoire. Annual report n ${ }^{\circ}$ 2212090 - 2019, (Rapport de recherche). DRAC/SRA (Directions Régionales des Affaires Culturelles / Service Régional d'Archéologie) Auvergne Rhône Alpes, Auvergne Rhône Alpes, Lyon, 199 p. (in French) ("Creation of a Pigment Library: A tool for understanding the supply of colouring materials in prehistoric times”) URL: https://hal.archives-ouvertes.fr/hal-02429867

Salomon, H., Coquinot, Y., Beck, L., Vignaud, C., Lebon, M., Odin, G. P., Mathis, F. \& Julien M. 2014, Stratégies spécialisées d'acquisition de pigments rouges durant le châtelperronien de la grotte du Renne à Arcy-sur-Cure (Yonne, France). Supplément Paléo: 125-133. (in French) ("Specialised strategies for the acquisition of red pigments during the Chatelperronian period in the Renne cave at Arcy-sur-Cure (Yonne, France)") 
Salomon, H., Goemaere, E., Billard, C., Dreesen, R., Bosquet, D., Hamon, C. \& Jadin, I. 2016, Analyse critique du protocole de caractérisation des hématites oolithiques mis en place dans le cadre du projet collectif de recherche sur l'origine des hématites oolithiques exploitées durant la préhistoire récente entre l’Eifel (de) et la Normandie (fr). In: About haematite. Procurement and transformation during Recent Prehistory. Proceedings of the international Round Table, 7-8/02/2013, Namur (Jambes) (Billard, C., Bosquet, D., Dreesen, R., Goemaere, É., Hamon, C., Jadin, I., Salomon, H. \& Savary, X., Eds.), Anthropologica et Praehistorica. Vol. 125, Societe Royale Belge d'Anthropologie et de Prehistoire, Bruxelles: p. 225-246. (in French) ("Critical analysis of the characterisation protocol of oolitic hematites set up within the framework of the collective research project on the origin of oolitic hematites exploited during recent prehistory between the Eifel (de) and Normandy (fr)”)

Salomon, J.-N. \& Pomel, S. 2005, Karst et mines. Accumulations et gisements de fer dans les terrains karstiques: exemple du Périgord et du Jura Franconnien. Travaux du Laboratoire de Géographie Physique Appliquée, 23: 11-20. (in French) ("Karst and mining. Accumulations and iron deposits in karst terrains: Example of the Périgord and the Franconian Jura”)

San Juan, C. 1990, Les matières colorantes dans les collections du Musée National de Préhistoire des Eyzies. Paléo, Revue d'Archéologie Préhistorique, 2(1): 229-242. (in French) ("Colouring materials in the collections of the National Prehistory Museum of Les Eyzies”)

Simon-Coinçon, R., Thiry, M. \& Quesnel, F. 2000, Paléopaysages et paléoenvironnements sidérolithiques du Nord du Massif central (France). Comptes Rendus de l'Académie des Sciences-Series IIA-Earth and Planetary Science, 330(10): 693-700. (in French) ("Paleo-landscapes and siderolithic paleo-environments of the northern Massif Central (France)”) doi:10.1016/S1251-8050(00)00189-0

Stanton, R.L. 1972, Ore Petrology. McGraw-Hill, New York, 771 p.

Thelemann, M., Bebermeier, W., Hoelzmann, P. \& Lehnhardt, E. 2017, Bog iron ore as a resource for prehistoric iron production in Central Europe - A case study of the Widawa catchment area in eastern Silesia, Poland. CATENA, 149: 474-90. doi:10.1016/j.catena.2016.04.002

Thiry, M., Franke, C., Collin, P.Y. \& Baudin, F. 2011, Excursion géologique - Le Morvan et ses bordures: sédimentation, paléoaltération, géodynamique et géomorphologie - 06-09 juin 2011, Support de cours, NR110525MTHI, Centre de Géosciences, Ecole des Mines de Paris, Fontainebleau, France, 62 p. (in French) ("Geological field trip - The Morvan and its borders: Sedimentation, paleoalteration, geodynamics and geomorphology - 06-09 June 2011, Course material, NR110525MTHI”)

Thiry, M., Quesnel, F., Yans, J., Wyns, R., Vergari, A., Théveniaut, H., Simon-Coinçon, R., Ricordel, C., Moreau, M.-G., Giot, D., Dupuis, C., Bruxelles, L., Barabrand, J. \& Baele, J.-M. 2006, Continental France and Belgium during the Early Cretaceous:

Paleoweatherings and paleolandforms. Bulletin de la société géologique de France, 177(3), 155-175. doi:10.2113/gssgfbull.177.3.155 
Thiry, M., Simon-Coinçon, R., Quesnel, F. \& Wyns, R. 2005, Altération bauxitique associée aux argiles à chailles sur la bordure sud-est du bassin de Paris. Bulletin de la Société Géologique de France, 176(2), 199-214. (in French) ("Bauxitic weathering associated with limestone clays on the south-eastern edge of the Paris basin") doi:10.2113/176.2.199

Triat, J. M. 2010, Les ocres. CNRS Éditions, Paris, 198 p. (in French) (“The ochres”)

Tromeur, R. 1998, L'ocre, exactement, Cahiers Terres et Couleurs Editeurs, 1, Paris, 24 p. (in French) ("The ochre, precisely")

Tuffery, C., Fernandes, P., Delvigne, V., Bressy-Leandri, C. \& Renault, S. 2018, Collecte, gestion et valorisation des données sur les formations et les gîtes à silex en France: pour des plateformes cartographiques et de publications partagées. In: Session $n^{\circ}$ III-3 (CA) of the XVIIIe UISPP congress. Construire des référentiels partagés: Webmapping et archéologie Vol. 3 Vol. 1, ISTE Ltd. London, Paris, France: p. 8 p. (in French) ("Collecting, managing and promoting data on flint deposits and sites in France: For shared cartographic and publishing platforms”) doi:10.21494/iste.Op.2019.0351

Tuffery, C., Fernandes, P., Delvigne, V., Morala, A. 2018, Combinaison d'un SMA et d'un SIG pour aider à la prospection pétroarchéologique. Exploration d'une approche multiagents dans la modélisation des parcours naturels du silex, Archéologies numériques, Openscience, 2(1). (in French) ("Combining SMA and GIS to aid petroarcheological prospecting. Exploring a multi-agent approach to flint pathway modelling”) doi:10.21494/ISTE.OP.2018.0276

Udden, J.A. 2014, Mechanical Composition of Clastic Sediments. Geological Society of America Bulletin, 25: 655-744. doi:10.1130/GSAB-25-655

Valeton, I. 1996, Bauxites, Elsevier, Amsterdam, 226 p. (in French) (“Bauxites”)

Velliky, E. C., Barbieri, A., Porr, M., Conard, N. J. \& MacDonald, B. L. 2019, A preliminary study on ochre sources in Southwestern Germany and its potential for ochre provenance during the Upper Paleolithic. Journal of Archaeological Science: Reports, 27: 101977: 14 p. doi:10.1016/j.jasrep.2019.101977

Velliky, E. C., Porr, M. \& Conard, N. J. 2018, Ochre and pigment use at Hohle Fels cave: Results of the first systematic review of ochre and ochre-related artefacts from the Upper Palaeolithic in Germany. PloS one, 13(12), e0209874. doi:10.1371/journal.pone.0209874

Vinchon, C. 1984, Sédimentogenèse et métallogenèse du Permien du Dôme du Barrot: AlpesMaritimes, France. Documents du BRGM, 70, Edition of Bureau de recherches géologiques et minières, Orléans: 445 p. (in French) ("Sedimentogenesis and metallogenesis of the Permian of the Dôme du Barrot: Alpes-Maritimes, France”)

Wadley, L. 2013, Recognizing complex cognition through innovative technology in Stone Age and Palaeolithic sites. Cambridge Archaeological Journal, 23(2): 163-183. doi:10.1017/S0959774313000309

Waterlot, G., Beugnies, A. \& Bintz, J. 1973, Ardenne - Luxembourg. Guides géologiques régionaux. Masson, Paris, 206 p. (in French) (“Ardenne - Luxembourg. Regional geological guides”)

Watts, I. 2002, Ochre in the Middle Stone Age of southern Africa: Ritualised display or hide preservative? The South African Archaeological Bulletin, 57(175): 1-14. doi:10.2307/3889102 
Wentworth, C.K. 1922, A scale of grade and class terms for clastic sediments. The journal of geology, 30(5): 377-392. doi:10.1086/622910

Widdowson, M. 2007, Laterite and ferricrete. In: Geochemical sediments and landscapes (Nash, D.J. \& McLaren, S.J., Eds.), Chapter 3. Wiley, New Jersey, p. 45-94. doi:10.1002/9780470712917

Wreschner, E.E. 1980, Red ochre and human evolution: A case for discussion [and comments and reply]. Current Anthropology, 21(5): 631-644. doi:10.1086/202541

Yans, J. 2003, An overview of the saprolites of Belgium and their potential kaolinitic supplies to Mesozoic and Cainozoic sediments. Géologie de la France, 1: 33-37.

Zipkin, A. M., Ambrose, S. H., Hanchar, J. M., Piccoli, P. M., Brooks, A. S. \& Anthony, E. Y. 2017, Elemental fingerprinting of Kenya Rift Valley ochre deposits for provenance studies of rock art and archaeological pigments. Quaternary International, 430: 42-59. doi:10.1016/j.quaint.2016.08.032 